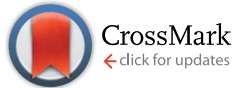

Cite this: RSC Adv., 2016, 6, 93476

Received 28th July 2016

Accepted 13th September 2016

DOI: 10.1039/c6ra19190h

www.rsc.org/advances

\section{Copper(I)-mediated synthesis of $\beta$-hydroxysulfones from styrenes and sulfonylhydrazides: an electrochemical mechanistic study $\uparrow$}

\begin{abstract}
Alexander O. Terent'ev, ${ }^{\star a b}$ Olga M. Mulina, ${ }^{a}$ Dmitry A. Pirgach, ${ }^{a b}$ Dmitry V. Demchuk, ${ }^{a}$ Mikhail A. Syroeshkin ${ }^{a}$ and Gennady I. Nikishin ${ }^{a}$

Copper(I) halides were used as mediators in the synthesis of $\beta$-hydroxysulfones via the oxysulfonylation of styrenes using sulfonylhydrazides. The feature of the developed process lies in the combination of a copper(I) salt with oxygen-the stoichiometric oxidant. Copper(॥) species are responsible for the oxidation of sulfonylhydrazides, they are generated in small amounts in the $\mathrm{O}_{2} / \mathrm{Cu}(\mathrm{I}) / \mathrm{Cu}\left({ }_{1}\right)$ redox system, which is formed during the reaction. The combination of these three components enables one to obtain in the case of $\alpha$-methylstyrenes only $\beta$-hydroxysulfones and in the case of $\alpha$-unsubstituted styrenes, $\beta$ hydroxysulfones as the main products and $\beta$-ketosulfones as the by-products. With good yields $\beta$ hydroxysulfones were prepared by reduction of the reaction mixture containing both products $\beta$ hydroxysulfones and $\beta$-ketosulfones with $\mathrm{NaBH}_{4}$. An electrochemical study revealed that the $\mathrm{Cu}\left({ }_{(}\right) / \mathrm{Cu}(\mathrm{Il})$ pair can serve as an effective mediator of $\beta$-hydroxysulfones formation via redox processes.
\end{abstract}

\section{Introduction}

$\beta$-Hydroxysulfones are of great interest as structural units of

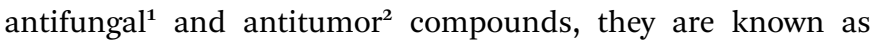
intermediates in the synthesis of lactones ${ }^{3}$ and unsymmetrical alkenes. ${ }^{4}$ Traditionally $\beta$-hydroxysulfones are obtained through the nucleophilic addition of sulfinates to epoxides, ${ }^{5-8}$ reduction of $\beta$-ketosulfones ${ }^{9,10}$ and hydroxylation of $\alpha, \beta$-unsaturated sulfones. ${ }^{11}$ Over the last few years, several oxidative strategies to prepare $\beta$-hydroxysulfones from olefins have been established. In these reports air and low thermally stable sulfinic acids ${ }^{\mathbf{1 2 - 1 4}}$ in combination with $\mathrm{O}_{2}$ and $\mathrm{PPh}_{3}$ (Scheme 1, eqn (1) $)^{15}$ or sulfonylhydrazides with $\mathrm{O}_{2}$ and $\mathrm{Fe}(\mathrm{III})$ salts are required.

The latter method was applied for the synthesis of structures containing the $\beta$-hydroxysulfone moiety predominantly at a tertiary carbon atom, which cannot be further oxidized (Scheme 1, eqn (2)). ${ }^{\mathbf{1 6}}$

For the sulfonylation of unsaturated compounds without additional insertion of oxygen into the molecule, a number of oxidants have been exploited: $\mathrm{Cu}(\mathrm{OAc})_{2},{ }^{17,18} \mathrm{CAN},{ }^{19} \mathrm{NBS},{ }^{20}$ $\mathrm{K}_{2} \mathrm{~S}_{2} \mathrm{O}_{8},{ }^{21}$ peroxides, ${ }^{22} \mathrm{I}_{2} / \mathrm{TBHP}^{23}$ and TBAI/TBHP ${ }^{24,25}$ systems. It is well-known that oxygen is an ideal environmentally friendly oxidant, which offers fascinating industrial and academic

${ }^{a}$ N. D. Zelinsky Institute of Organic Chemistry, Russian Academy of Sciences, Leninsky Prospect 47, Moscow, 119991, Russian Federation. E-mail: terentev@ioc.ac.ru; Fax: +7-499-1355328

${ }^{b}$ D. I. Mendeleev University of Chemical Technology of Russia, 9 Miusskaya square, Moscow, 125047, Russian Federation

$\dagger$ Electronic supplementary information (ESI) available: NMR spectra of all synthesized compounds. See DOI: 10.1039/c6ra19190h prospects. In oxidative transformations, in most cases, it is used in combination with transition metals salts and complexes. ${ }^{26-29}$

In this context, we have disclosed a process for the oxysulfonylation of styrenes utilizing sulfonylhydrazides in the presence of a $\mathrm{O}_{2} / \mathrm{Cu}(\mathrm{I})$ system, leading to $\beta$-hydroxysulfones. During the reaction the $\mathrm{O}_{2} / \mathrm{Cu}$ (I) $/ \mathrm{Cu}$ (II) system is formed with a small amount of $\mathrm{Cu}$ (II) as confirmed by the near absence of the specific colour of $\mathrm{Cu}$ (II) species. As a result, $\beta$-hydroxysulfones 3 as main products and $\beta$-ketosulfones $\mathbf{4}$ as by-products are formed (Scheme 2).

\section{Results and discussion}

The synthesis of $\beta$-hydroxysulfones 3aa-3fe and $\beta$-ketosulfones 4aa-4ab from styrenes $\mathbf{1 a - 1} \mathbf{j}$ with the use of sulfonylhydrazides

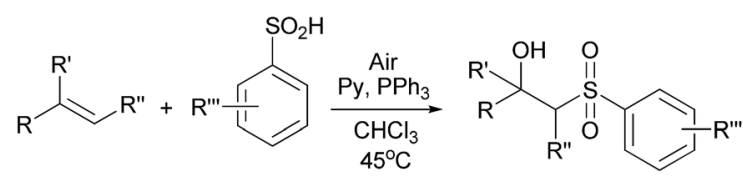

$\mathrm{R}=\mathrm{Ar} ; \mathrm{R}^{\prime}=\mathrm{H}, \mathrm{Alk} ; \mathrm{R}^{\prime \prime}=\mathrm{H}$, Alk $\mathrm{R}^{\prime \prime}=\mathrm{H}, \mathrm{Me}, \mathrm{Hal}, \mathrm{OMe}$

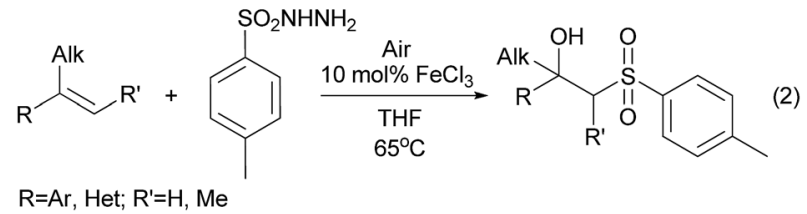

Scheme 1 Recent works for the oxysulfonylation of styrenes. 
<smiles>[R]C(=C)c1ccc([R])cc1</smiles>

1<smiles>[R]c1ccc(S(=O)(=O)NN)cc1</smiles>

2

$$
\mathrm{Cu}(\mathrm{l}) \longrightarrow \mathrm{Cu}(\mathrm{I}) / \mathrm{Cu}(\mathrm{II})
$$

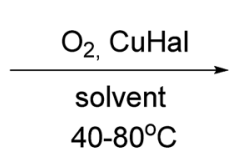

$40-80^{\circ} \mathrm{C}$

1a: $R=H, R^{\prime}=H ; 1 b: R=H, R^{\prime}=o-M e ;$

1c: $\mathrm{R}=\mathrm{H}, \mathrm{R}^{\prime}=p-{ }^{\mathrm{i}} \mathrm{Pr} ; 1 \mathrm{~d}: \mathrm{R}=\mathrm{H}, \mathrm{R}^{\prime}=p-{ }^{\mathrm{t}} \mathrm{Bu}$;

1e: $\mathrm{R}=\mathrm{H}, \mathrm{R}^{\prime}=p-\mathrm{Cl}$; $1 \mathrm{f}: \mathrm{R}=\mathrm{Me}, \mathrm{R}^{\prime}=\mathrm{H}$;

1g: $\mathrm{R}=\mathrm{Me}, \mathrm{R}^{\prime}=p-\mathrm{Cl} ; \mathbf{1 h}: \mathrm{R}=\mathrm{Me}, \mathrm{R}^{\prime}=p-\mathrm{Br}$;

1i: $\mathrm{R}=\mathrm{Me}, \mathrm{R}^{\prime}=p-\mathrm{NO}_{2} ; 1 \mathrm{j}: \mathrm{R}=\mathrm{Me}, \mathrm{R}=p-\mathrm{OMe}$<smiles>[R][X]1ccc(C([R])(O)CS(=O)(=O)c2ccc([Z7])cc2)cc1</smiles>

3aa, 3ba, 3ca, 3da, 3ea, 3ab, 3fa, 3ga, 3ha, 3ia, 3ja, 3fc, 3fd, 3fe<smiles>[R]c1ccc(S(=O)(=O)CC(=O)C2=C[I]([R])=CC=C2)cc1</smiles>

4aa, 4ba, 4ca, 4da, 4ea, 4ab

$\mathrm{R}^{\prime \prime}=2 \mathrm{a}(\mathrm{Me}), 2 \mathrm{~b}(\mathrm{I}), 2 \mathrm{c}(\mathrm{Br}), 2 \mathrm{~d}(\mathrm{OMe}), 2 \mathrm{e}\left(\mathrm{NO}_{2}\right)$

Scheme 2 The oxysulfonylation of styrenes $1 a-1 j$ using sulfonylhydrazides $2 a-2 e$ (in the codification of 3 and 4 the first letter index refers to the styrene 1 moiety, the second letter index to the hydrazide 2 moiety).

2a-2e was conducted in $\mathrm{CH}_{3} \mathrm{CN}, \mathrm{CH}_{3} \mathrm{CN}-\mathrm{H}_{2} \mathrm{O}$, THF and THF$\mathrm{H}_{2} \mathrm{O}$ using a $\mathrm{O}_{2} / \mathrm{Cu}(\mathrm{I}) / \mathrm{Cu}(\mathrm{II})$ redox system. This system was a result of the transformation of $\mathrm{CuCl}, \mathrm{CuBr}$ and $\mathrm{CuI}$ under aerobic conditions (Scheme 2).

Our preliminary studies were focused on the reaction of styrene 1a with sulfonylhydrazide 2a, leading to the formation of 1-phenyl-2-tosylethanol 3aa and 1-phenyl-2-tosylethanone 4aa. We examined the influence of the $\mathrm{Cu}(\mathrm{I})$ salt counter-ion, oxygen source (air oxygen or $98 \%$ oxygen) and solvent type (Table 1) on the yield of 3aa.

Entries 1-3 indicated that among the copper(I) halides ( $\mathrm{CuBr}, \mathrm{CuCl}$ and $\mathrm{CuI}$ ), the use of $\mathrm{CuBr}$ afforded the highest total yield of oxysulfonylation products and the yield of the desired product 3aa after $7 \mathrm{~h}$. When the reaction was performed for a more prolonged time (entry 4) the yield of 3aa reached $38 \%$. Heating the reaction mixture for the first $7 \mathrm{~h}$ to $80^{\circ} \mathrm{C}$ (entry 5) didn't increase the yield of 3aa. Decreasing (entry 6) or increasing (entry 7) the molar ratio of $\mathrm{CuBr}$ per mol of $\mathbf{1 a}$ in comparison with the previous entries resulted in a reduced yield of the desired product. Employing $\mathrm{CH}_{3} \mathrm{CN}$, THF or THF- $\mathrm{H}_{2} \mathrm{O}$ $(5: 1)$ in place of $\mathrm{CH}_{3} \mathrm{CN}-\mathrm{H}_{2} \mathrm{O}(5: 1)$ negatively influenced the reaction efficiency (entries $8-10$ ). In entry 11 , air oxygen was replaced with $98 \%$ oxygen and as a result the yield of 3aa was improved to $55 \%$, the total yield of oxysulfonylation products in this case reached $91 \%$. Attempts failed (entries 12-14) to increase the yield of desired product through modification of

Table 1 Screening of the reaction conditions $^{a}$
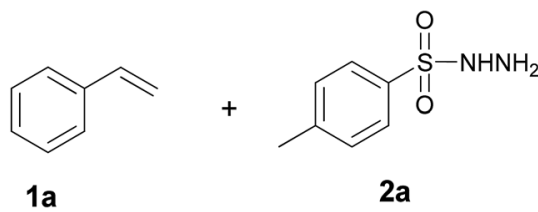

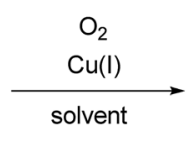

2a<smiles>Cc1ccc(S(=O)(=O)CC(O)c2ccccc2)cc1</smiles>

3aa

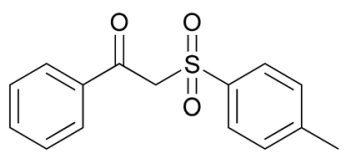

4aa

\begin{tabular}{|c|c|c|c|c|c|c|c|}
\hline Entry & Time (h) & Ratio (mole Cu(I)/mole 1a) & Oxygen source & Solvent & Yield $3 \mathbf{a a}^{b}(\%)$ & Yield $\mathbf{4 a a}^{b}(\%)$ & Total yield $\mathbf{3 a a}$ and $\mathbf{4} \mathbf{a a}^{b}(\%)$ \\
\hline 1 & 7 & $\mathrm{CuBr}(2)$ & Air & $\mathrm{CH}_{3} \mathrm{CN}-\mathrm{H}_{2} \mathrm{O}$ & 28 & 14 & 42 \\
\hline 2 & 7 & $\mathrm{CuCl}(2)$ & Air & $\mathrm{CH}_{3} \mathrm{CN}-\mathrm{H}_{2} \mathrm{O}$ & 25 & 15 & 40 \\
\hline $4^{c}$ & $7+12$ & $\operatorname{CuBr}(2)$ & Air & $\mathrm{CH}_{3} \mathrm{CN}-\mathrm{H}_{2} \mathrm{O}$ & $38(61)$ & 27 & 65 \\
\hline $5^{d}$ & $7+12$ & $\mathrm{CuBr}(2)$ & Air & $\mathrm{CH}_{3} \mathrm{CN}-\mathrm{H}_{2} \mathrm{O}$ & 30 & 16 & 46 \\
\hline 6 & $7+12$ & $\mathrm{CuBr}(0.2)$ & Air & $\mathrm{CH}_{3} \mathrm{CN}-\mathrm{H}_{2} \mathrm{O}$ & 10 & 5 & 15 \\
\hline 9 & $7+12$ & $\mathrm{CuBr}(2)$ & Air & THF & 28 & 13 & 41 \\
\hline 10 & $7+12$ & $\mathrm{CuBr}(2)$ & Air & $\mathrm{THF}-\mathrm{H}_{2} \mathrm{O}$ & 18 & 10 & 28 \\
\hline 11 & $7+12$ & $\mathrm{CuBr}(2)$ & $\mathrm{O}_{2}$ & $\mathrm{CH}_{3} \mathrm{CN}-\mathrm{H}_{2} \mathrm{O}$ & $55(85)$ & 36 & 91 \\
\hline 12 & $7+12$ & $\mathrm{CuBr}(0.2)$ & $\mathrm{O}_{2}$ & $\mathrm{CH}_{3} \mathrm{CN}-\mathrm{H}_{2} \mathrm{O}$ & 15 & 8 & 23 \\
\hline 13 & 7 & $\mathrm{CuBr}(2)$ & $\mathrm{O}_{2}$ & $\mathrm{CH}_{3} \mathrm{CN}-\mathrm{H}_{2} \mathrm{O}$ & $43(71)$ & 35 & 78 \\
\hline $14^{d}$ & $7+12$ & $\mathrm{CuBr}(2)$ & $\mathrm{O}_{2}$ & $\mathrm{CH}_{3} \mathrm{CN}-\mathrm{H}_{2} \mathrm{O}$ & $50(77)$ & 30 & 80 \\
\hline
\end{tabular}

${ }^{a}$ General procedure: to a solution of styrene $1 \mathrm{a}(300 \mathrm{mg}, 2.88 \mathrm{mmol})$ in $25 \mathrm{~mL}$ of $\left(\mathrm{CH}_{3} \mathrm{CN}-\mathrm{H}_{2} \mathrm{O}(5: 1), \mathrm{CH}_{3} \mathrm{CN}, \mathrm{THF}, \mathrm{THF}-\mathrm{H}_{2} \mathrm{O}(5: 1)\right)$, the Cu(I) salt (0.58-14.4 mmol, molar ratio $0.2-5 \mathrm{~mol}$ of salt $/ \mathrm{mol} \mathrm{1a)}$ and sulfonylhydrazide $2 \mathrm{a}(537 \mathrm{mg}, 2.88 \mathrm{mmol}$, molar ratio $1 \mathrm{~mol} \mathrm{2a} / \mathrm{mol} \mathrm{1a)}$ were added. The mixture was stirred for $7 \mathrm{~h}$ at $40{ }^{\circ} \mathrm{C} .{ }^{b}$ The yield was determined by ${ }^{1} \mathrm{H}$ NMR using 1,4-dinitrobenzene as an internal standard, the isolated yield after reduction with $\mathrm{NaBH}_{4}$ is reported in the parentheses. ${ }^{c} 7 \mathrm{~h}$ at $40{ }^{\circ} \mathrm{C}$, then $12 \mathrm{~h}$ at $20-25^{\circ} \mathrm{C} .{ }^{d} 7 \mathrm{~h}$ at $80{ }^{\circ} \mathrm{C}$, then $12 \mathrm{~h}$ at $20-25{ }^{\circ} \mathrm{C}$. 
the molar ratio of $\mathrm{CuBr}$ per mol of $\mathbf{1 a}$, temperature and reaction time when compared to the conditions of entry 11, in which the best result was obtained; the total yield of 3aa and 4aa in these experiments didn't exceed $80 \%$.

With the optimized reaction conditions in hand (entry 11, Table 1), the scope of the copper-mediated oxysulfonylation reaction was investigated. A number of $\beta$-hydroxysulfones 3aa3ab were formed in 32-65\% yield with $\beta$-ketosulfones 4aa-4ab observed as the by-products of the reaction in 18-33\% yield (Table 2).

In all the examples, hydroxysulfone was predominantly formed independently of the properties of the substituents on the benzene ring. In most cases, the molar ratio of $\beta$-hydroxysulfone $3 /$ ketosulfone 4 was $2: 1$. It is well-known that ketones can be easily reduced into their corresponding alcohols. ${ }^{30-32}$ That's why in order to transform the $\beta$-ketosulfones 4 byproducts into the desired $\beta$-hydroxysulfones 3 we filtered the reaction mixture from the $\mathrm{CuBr}$ after the reaction was complete and then carried out the reduction of the ketosulfones using

Table 2 The structure and yield of $\beta$-hydroxysulfones 3 and $\beta$-ketosulfones $4^{a}$<smiles>Cc1ccc(S(=O)(=O)CC(O)c2ccccc2)cc1</smiles>

3aa, $55 \%$ (85\%)<smiles>Cc1ccc(S(=O)(=O)CC(=O)c2ccccc2)cc1</smiles>

4aa, $36 \%$<smiles>Cc1ccc(S(=O)(=O)CC(O)c2ccc(C(C)C)cc2)cc1</smiles>

$3 c a, 53 \%(72 \%)$<smiles>Cc1ccc(S(=O)(=O)CC(=O)c2ccc(C(C)C)cc2)cc1</smiles>

$4 \mathrm{ca}, 23 \%$<smiles>Cc1ccc(S(=O)(=O)CC(O)c2ccc(Cl)cc2)cc1</smiles>

3ea, $32 \%(52 \%)$<smiles>Cc1ccc(S(=O)(=O)CC(=O)c2ccc(Cl)cc2)cc1</smiles>

4ea, $24 \%$<smiles>Cc1ccc(S(=O)(=O)CC(O)c2ccccc2C)cc1</smiles>

3ba, 37\% (54\%)<smiles>Cc1ccc(S(=O)(=O)CC(=O)c2ccccc2C)cc1</smiles>

4ba, $18 \%$<smiles>Cc1ccc(S(=O)(=O)CC(O)c2ccc(C(C)(C)C)cc2)cc1</smiles>

3da, 65\% (89\%)<smiles>Cc1ccc(S(=O)(=O)CC(=O)c2ccc(C(C)(C)C)cc2)cc1</smiles>

4da, $31 \%$<smiles>O=S(=O)(CC(O)c1ccccc1)c1ccc(I)cc1</smiles>

3ab, $40 \%$ (62\%)<smiles>O=C(CS(=O)(=O)c1ccc(I)cc1)c1ccccc1</smiles>

4ab, $25 \%$

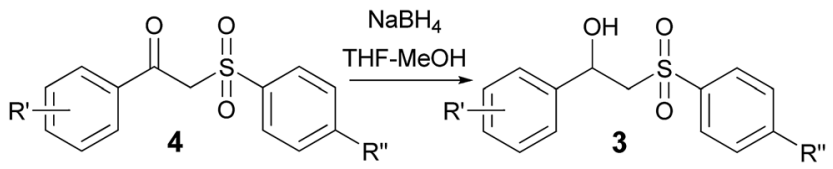

Scheme 3 The reduction of $\beta$-ketosulfones using $\mathrm{NaBH}_{4}$.

$\mathrm{NaBH}_{4}$ (Scheme 3). As a result, the desired $\beta$-hydroxysulfones 3 were obtained in a 52-89\% overall yield over two steps (Table 2 and entries 4, 11, 13, 14 in Table 1).

The oxysulfonylation reaction was also examined by applying of $\alpha$-methylstyrenes (Table 3 ). A variety of $\alpha$-methylstyrenes bearing either electron withdrawing or electron donating substituents on the aryl ring worked well under the conditions of entry 11 (Table 1 ) and the target $\beta$-hydroxysulfones were formed in most cases in good yield. It is important to note that in the reactions of methylsulfonylhydrazide with styrene $\mathbf{1 a}$ and octene-1 or cyclohexene with sulfonylhydrazide $\mathbf{2 a}$ the oxysulfonylation products were not observed in measurable yield.

The structures of all the synthesized hydroxysulfones 3 and ketosulfones 4 were confirmed by ${ }^{1} \mathrm{H}$ and ${ }^{13} \mathrm{C}$ NMR spectroscopy, elemental analysis, HRMS and IR spectroscopy.

\section{Proposed reaction mechanism}

To study the plausible reaction mechanism, an investigation of the redox properties of oxygen, styrene 1a, $p$-toluenesulfonylhydrazide $2 \mathrm{a}$ and $\mathrm{CuBr}$ in $\mathrm{CH}_{3} \mathrm{CN}-\mathrm{H}_{2} \mathrm{O}(5: 1)$ with the use of cyclic voltammetry (CV) was carried out. Tetrabutylammonium perchlorate was chosen as a supporting electrolyte. The obtained CV curves are shown in Fig. 1.

Table 3 The structure and yield of $\beta$-hydroxysulfones $3^{a}$<smiles>Cc1ccc(S(=O)(=O)CC(C)(O)c2ccccc2)cc1</smiles>

$3 \mathrm{fa}, 92 \%$<smiles>Cc1ccc(S(=O)(=O)CC(O)(O)c2ccc(Br)cc2)cc1</smiles>

3ha, $93 \%$<smiles>COc1ccc(C(C)(O)CS(=O)(=O)c2ccc(C)cc2)cc1</smiles>

3ja, $90 \%$<smiles>COc1ccc(S(=O)(=O)CC(C)(O)c2ccccc2)cc1</smiles>

$3 f d, 85 \%$<smiles>Cc1ccc(S(=O)(=O)CC(C)(O)c2ccc(Cl)cc2)cc1</smiles>

3ga, $90 \%$<smiles>Cc1ccc(S(=O)(=O)CC(O)(O)c2ccc([N+](=O)[O-])cc2)cc1</smiles>

3ia, $89 \%$<smiles>CC(O)(CS(=O)(=O)c1ccc(Br)cc1)c1ccccc1</smiles>

$3 \mathrm{fc}, 52 \%$<smiles>CC(O)(CS(=O)(=O)c1ccc([N+](=O)[O-])cc1)c1ccccc1</smiles>

3fe, $36 \%$
${ }^{a}$ The yield was determined by ${ }^{1} \mathrm{H}$ NMR using 1 ,4-dinitrobenzene as an internal standard; the isolated yield after reduction with $\mathrm{NaBH}_{4}$ is reported in the parentheses.
${ }^{a}$ Isolated yield. 


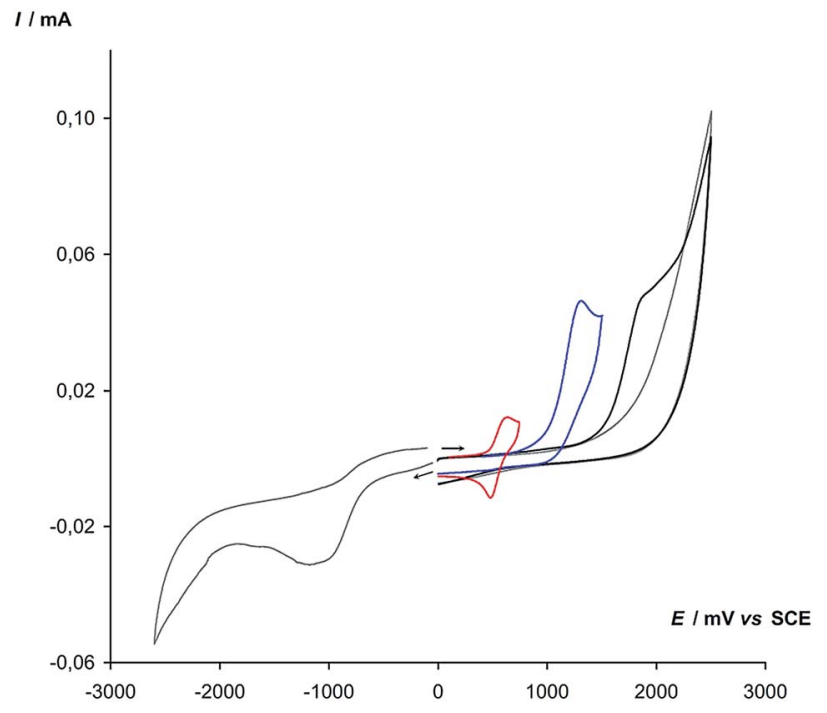

Fig. 1 The CV curves obtained for $2.0 \mathrm{mmol} \mathrm{L}^{-1}$ solutions of $\mathrm{CuBr}$ (red), $p$-toluenesulfonylhydrazide $2 a$ (blue), styrene $1 \mathrm{a}$ (black) and aerated supporting solution (grey) in $0.1 \mathrm{M} \mathrm{Bu}_{4} \mathrm{NClO}_{4}$ in $\mathrm{CH}_{3} \mathrm{CN}-\mathrm{H}_{2} \mathrm{O}$ (5: 1$)$ on a working glassy-carbon electrode $(d=1.7 \mathrm{~mm})$ at a scan rate of $100 \mathrm{mV} \mathrm{s}^{-1}$.

The oxidizing properties of oxygen are evidenced in reducing at the relatively early potentials, the peak on the $\mathrm{CV}$ curve with potential $-1.10 \mathrm{~V}$ was responsible for its reduction. The chemically irreversible oxidation of styrene 1 a takes place in the far region with a maximum at $1.90 \mathrm{~V}$ and runs into the discharge of the background. A chemically irreversible peak at $1.35 \mathrm{~V}$ was responsible for the oxidation of p-toluenesulfonylhydrazide $\mathbf{2 a}$. Therefore, we can conclude that its oxidation goes rather more easily than the oxidation of styrene.

A chemically and electrochemically reversible peak at $E_{1 / 2}=$ $0.55 \mathrm{~V}$ corresponds to the oxidation of $\mathrm{Cu}(\mathrm{I})$ into $\mathrm{Cu}(\mathrm{II})$, which takes place in the potential range between oxygen reduction and $p$-toluenesulfonylhydrazide $2 \mathrm{a}$ oxidation. This means that under experimental conditions the $\mathrm{Cu}(\mathrm{I}) / \mathrm{Cu}(\mathrm{II})$ couple can serve as an effective mediator of $p$-toluenesulfonylhydrazide $\mathbf{2 a}$ oxidation using oxygen.

On the basis of the obtained experimental data and previous studies of reactions proceeding through the generation of $\mathrm{S}$ centered radicals from sulfonylhydrazides, ${ }^{33-35}$ we proposed the pathway of the oxysulfonylation process (Scheme 4). $\mathrm{Cu}(\mathrm{I})$ ions are oxidized to $\mathrm{Cu}(\mathrm{II})^{36-40}$ in the presence of oxygen, as confirmed by numerous kinetic studies of this process. ${ }^{41-44}$ An almost colourless solution during the reaction is evidence for a small amount of $\mathrm{Cu}$ (II). Afterwards, as a result of the successive oxidation of hydrazide $2 \mathrm{a}$ under the action of $\mathrm{Cu}(\mathrm{II}),{ }^{16,33,34}$ oxygen or peroxyradical C, an S-centered tosyl radical A (Ts) is generated, which reacts with styrene $\mathbf{1 a}$ to form a C-centered benzyl radical $\mathbf{B} .^{16}$ In the next step, radical $\mathbf{B}$ is trapped with oxygen forming peroxyradical $\mathbf{C}$. Then, after abstraction of an hydrogen atom from a hydrogen donor $\mathrm{X}-\mathrm{H}(\mathrm{NH}$ and $\mathrm{CH})$ the peroxyradical $\mathbf{C}$ transforms into hydroperoxide $\mathbf{D},{ }^{45}$ which gives the main product 3aa after reduction. ${ }^{\mathbf{4 6 - 5 1}}$ Alcohol 3aa can also

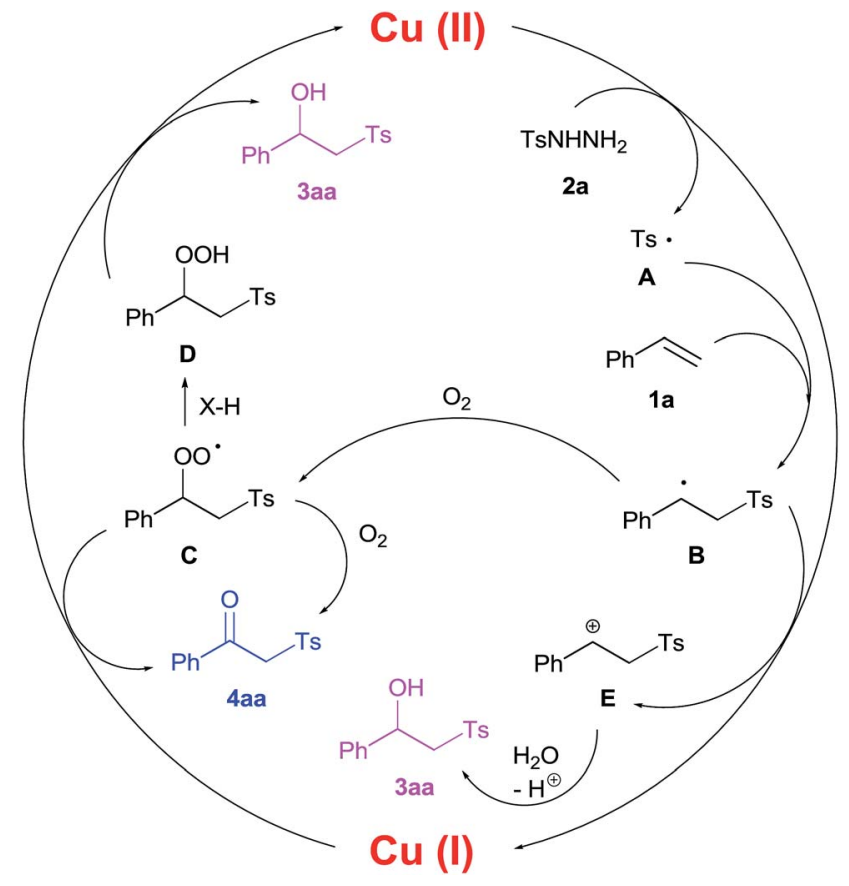

Scheme 4 A plausible oxysulfonylation mechanism using the example of the reaction of styrene $1 \mathrm{a}$ and $p$-toluenesulfonylhydrazide $2 \mathrm{a}$.

be formed due to $\mathrm{C}$-centered benzyl radical $\mathbf{B}$ oxidation by $\mathrm{Cu}(\mathrm{II})$ species to the intermediate cation $\mathbf{E}$ followed by its hydroxylation. ${ }^{52-54}$ Ketone 4 aa is formed after the fragmentation of the species generated from the reaction of peroxyradical $\mathbf{C}$ with $\mathrm{Cu}(\mathrm{I})$ ions ${ }^{55}$ or oxygen. ${ }^{56-58}$

The fact that using of octene- 1 and cyclohexene as starting reagents didn't lead to the formation of oxysulfonylation products can be explained by the low stability of the C-centered alkyl radical generated after addition of tosyl radical $\mathbf{A}$ to their double bonds.

\section{Conclusions}

In summary, we have demonstrated a novel copper-mediated oxysulfonylation of styrenes using sulfonylhydrazides for the synthesis of $\beta$-hydroxysulfones in 32-93\% yield. In the case of $\alpha$ unsubstituted styrenes, $\beta$-ketosulfones are formed as the byproducts. Applying $\alpha$-methylstyrenes in this methodology gives $\beta$-hydroxysulfones as single products in high yield. Moreover, using cyclic voltammetry, experimental data and previous reports, a plausible reaction pathway was proposed. Coupling of two starting reagents proceeds under the action of the $\mathrm{O}_{2} / \mathrm{Cu}(\mathrm{I}) / \mathrm{Cu}(\mathrm{II})$ redox system. The distinguishing feature of the work lies in the combination of oxygen and a copper(I) salt, which is oxidized to copper(II) on a limited scale, which makes it possible to obtain $\beta$-hydroxysulfones as the main products.

\section{Experimental}

NMR spectra were recorded on a Bruker Avance II $300 \mathrm{MHz}$ instrument. Chemical shifts are measured relative to the residual solvent peaks as an internal standard set to $\delta 7.25$ and 
$\delta 77.0\left(\mathrm{CDCl}_{3}\right)$, and $\delta 2.50$ and $\delta 39.51\left(\mathrm{DMSO}_{6}\right)$. IR spectra were recorded on a FT-IR spectrometer. High resolution mass spectra (HRMS) were measured using electrospray ionization (ESI). ${ }^{59}$ The measurements were carried out in positive ion mode (interface capillary voltage $4500 \mathrm{~V}$ ); the mass ratio was from $\mathrm{m} / \mathrm{z} 50$ to $3000 \mathrm{Da}$; external/internal calibration was performed using an electrospray calibrant solution. Syringe injection was used for solutions in $\mathrm{CH}_{3} \mathrm{CN}$ (flow rate $3 \mu \mathrm{L} \mathrm{min}{ }^{-1}$ ). Nitrogen was applied as a dry gas and the interface temperature was set at $180{ }^{\circ} \mathrm{C}$. TLC analyses were carried out on standard silica-gel chromatography plates. Melting points were determined on a Kofler hot-stage apparatus. Chromatography was performed on silica gel (63-200 mesh).

Vinylbenzene (1a), 1-methyl-2-vinylbenzene (1b), 1-tert-butyl-4vinylbenzene (1d), 1-chloro-4-vinylbenzene (1e), isopropenylbenzene (1f), $p$-toluenesulfonohydrazide (2a), 4-iso-propylbenzaldehyde, 4-chloroacetophenone, 4-bromoacetophenone, 4-nitroacetophenone, 4-methoxyacetophenone, 4-iodobenzene-sulfonylchloride, 4-bromobenzenesulfonylchloride, 4-methoxy-benzenesulfonylchloride, 4-nitrobenzenesulfonylchloride, methyltri-phenylphosphonium bromide, $t$-BuOK, $\mathrm{Na}_{2} \mathrm{SO}_{4}$, tetra-butylammonium perchlorate, $\mathrm{CuBr}, \mathrm{CH}_{3} \mathrm{CN}, \mathrm{THF}, \mathrm{CHCl}_{3}, \mathrm{CH}_{2} \mathrm{Cl}_{2}$, $\mathrm{MeOH}$, petroleum ether (PE, 40/70), ethyl acetate (EA) and hydrazine hydrate $(64 \% \mathrm{w} / \mathrm{w}$ water solution of hydrazine) were purchased from commercial sources and were used as received. 1-Iso-propyl-4-vinylbenzene (1c), 1-chloro-4-isopropenylbenzene (1g), 1-bromo-4-isopropenylbenzene (1h), 1-nitro-4-isopropenylbenzene (1i) and 1-methoxy-4-isopropenylbenzene (1j) were synthesized via the Wittig reaction according to the literature. ${ }^{60}$ 4-Iodobenzenesulfono-hydrazide (2b), 4-bromobenzenesulfonohydrazide (2c), 4-methoxy-benzenesulfonohydrazide (2d) and 4nitrobenzenesulfonohydrazide (2e) were synthesized according to the literature. ${ }^{61}$

Cyclic voltammetry (CV) was implemented on an IPC-Pro computer-assisted potentiostat manufactured by Econix (scan rate error $1.0 \%$; potential setting $0.25 \mathrm{mV}$ ). The experiments were performed in a $10 \mathrm{~mL}$ five-neck glass conic electrochemical cell with a water jacket for thermostatting. CV curves were recorded using a three-electrode scheme. The working electrode was a disc glassy-carbon electrode $(d=1.7 \mathrm{~mm})$. A platinum wire served as an auxiliary electrode. A saturated calomel electrode was used as the reference electrode and was linked to the solution by a bridge with a porous ceramic diaphragm filled with background electrolyte. The tested solutions were thermostatted at $25 \pm 0.5^{\circ} \mathrm{C}$. In a typical case, $5 \mathrm{~mL}$ of solution was utilized and the depolarizer concentration was $2 \mathrm{mmol} \mathrm{L}^{-1}$. The working electrode was polished before recording each CV curve.

\section{Synthesis of styrenes $1 \mathrm{c}, \mathbf{1 g}-\mathbf{1 j}$}

Following a literature procedure ${ }^{60}$ to a solution of methyltriphenylphosphonium bromide (14.3-19.1 g, 39.9-53.4 mmol) in THF (50 mL), $t$-BuOK (4.8-6.5 g, 43.1-57.7 mmol) was added with vigorous stirring under an Ar atmosphere for $10 \mathrm{~min}$. The mixture was stirred for $1 \mathrm{~h}$ at room temperature. Then, the corresponding carbonyl compound (4-iso-propylbenzaldehyde, 4-chloroacetophenone, 4-bromoacetophenone, 4-nitroaceto- phenone or 4-methoxyacetophenone, $3.0 \mathrm{~g}, 15.1-20.2 \mathrm{mmol}$ ) was added. The mixture was stirred for $24 \mathrm{~h}$ at room temperature. Then, the mixture was diluted with $\mathrm{CH}_{2} \mathrm{Cl}_{2}(180 \mathrm{~mL})$, washed with water $(3 \times 15 \mathrm{~mL})$ and dried over $\mathrm{Na}_{2} \mathrm{SO}_{4}$. The solvent was removed under reduced pressure (10-20 Torr). Styrenes 1c, $\mathbf{1 g}-\mathbf{1 j}$ were isolated by chromatography on $\mathrm{SiO}_{2}$ with elution using PE-EA with a linear gradient of the latter from 0 to $10 \mathrm{vol} \%$.

1-Isopropyl-4-vinylbenzene (1c). ${ }^{62}$ 4-Iso-propylbenzaldehyde $(3.0 \mathrm{~g}, 20.2 \mathrm{mmol}$ ) gave the title compound as a colourless oil (2.2 g, $15.2 \mathrm{mmol}, 75 \%) .{ }^{1} \mathrm{H}$ NMR $\left(\mathrm{CDCl}_{3}\right), \delta: 1.24(\mathrm{~d}, J=6.9 \mathrm{~Hz}$, $6 \mathrm{H}), 2.80-2.96(\mathrm{~m}, 1 \mathrm{H}), 5.17$ (dd, $J=10.9,1.1 \mathrm{~Hz}, 1 \mathrm{H}), 5.69$ (dd, $J$ $=17.6,1.1 \mathrm{~Hz}, 1 \mathrm{H}), 6.68(\mathrm{dd}, J=17.6,10.9 \mathrm{~Hz}, 1 \mathrm{H}), 7.17(\mathrm{~d}, J=$ $8.1 \mathrm{~Hz}, 2 \mathrm{H}), 7.33(\mathrm{~d}, J=8.0 \mathrm{~Hz}, 2 \mathrm{H}) .{ }^{13} \mathrm{C} \mathrm{NMR}\left(\mathrm{CDCl}_{3}\right), \delta: 23.9$, 33.9, 112.8, 126.2, 126.6, 135.2, 136.7, 148.6.

1-Chloro-4-isopropenylbenzene (1g) ${ }^{63}$ 4-Chloroacetophenone $(3.0 \mathrm{~g}, 19.4 \mathrm{mmol})$ gave the title compound as a colourless oil ( 2.3 $\mathrm{g}, 15.1 \mathrm{mmol}, 78 \%) .{ }^{1} \mathrm{H} \mathrm{NMR}\left(\mathrm{CDCl}_{3}\right), \delta: 2.13(\mathrm{~s}, 3 \mathrm{H}), 5.10(\mathrm{~s}, 1 \mathrm{H})$, $5.36(\mathrm{~s}, 1 \mathrm{H}), 7.29(\mathrm{~d}, J=8.6 \mathrm{~Hz}, 2 \mathrm{H}), 7.39(\mathrm{~d}, J=8.6 \mathrm{~Hz}, 2 \mathrm{H}) .{ }^{13} \mathrm{C}$ NMR $\left(\mathrm{CDCl}_{3}\right), \delta: 21.7,112.9,126.8,128.3,133.1,139.6,142.1$.

1-Bromo-4-isopropenylbenzene (1h).${ }^{64}$ 4-Bromoacetophenone $(3.0 \mathrm{~g}, 15.1 \mathrm{mmol})$ gave the title compound as a colourless oil (2.1 $\mathrm{g}, 10.6 \mathrm{mmol}, 70 \%) .{ }^{1} \mathrm{H} \mathrm{NMR}\left(\mathrm{CDCl}_{3}\right), \delta: 2.13(\mathrm{~s}, 3 \mathrm{H}), 5.11(\mathrm{~s}, 1 \mathrm{H})$, $5.36(\mathrm{~s}, 1 \mathrm{H}), 7.33(\mathrm{~d}, J=8.6 \mathrm{~Hz}, 2 \mathrm{H}), 7.45(\mathrm{~d}, J=8.6 \mathrm{~Hz}, 2 \mathrm{H}) .{ }^{13} \mathrm{C}$ NMR $\left(\mathrm{CDCl}_{3}\right), \delta: 21.6,113.0,121.3,127.1,131.2,140.1,142.2$.

1-Isopropenyl-4-nitrobenzene (1i). ${ }^{65}$ 4-Nitroacetophenone $(3.0 \mathrm{~g}, 18.2 \mathrm{mmol})$ gave the title compound as a yellow oil $(1.9 \mathrm{~g}$, $11.8 \mathrm{mmol}, 65 \%) .{ }^{1} \mathrm{H} \mathrm{NMR}\left(\mathrm{CDCl}_{3}\right), \delta: 2.17$ (s, 3H), $5.28(\mathrm{~s}, 1 \mathrm{H})$, $5.51(\mathrm{~s}, 1 \mathrm{H}), 7.57(\mathrm{~d}, J=8.9 \mathrm{~Hz}, 2 \mathrm{H}), 8.15(\mathrm{~d}, J=8.9 \mathrm{~Hz}, 2 \mathrm{H}) .{ }^{13} \mathrm{C}$ NMR $\left(\mathrm{CDCl}_{3}\right), \delta: 21.5,116.3,123.5,126.2,141.5,146.9,147.6$.

1-Isopropenyl-4-methoxybenzene $\quad(\mathbf{1 j}) .{ }^{66} \quad$ 4-Methoxyacetophenone $(3.0 \mathrm{~g}, 20.0 \mathrm{mmol})$ gave the title compound as a white solid (2.4 g, $16.0 \mathrm{mmol}, 80 \%) . \mathrm{Mp}=30.5-31.0{ }^{\circ} \mathrm{C}\left(\right.$ lit. $^{66} \mathrm{mp}=$ 32.0-32.5 $\left.{ }^{\circ} \mathrm{C}\right) .{ }^{1} \mathrm{H}$ NMR $\left(\mathrm{CDCl}_{3}\right), \delta: 2.15(\mathrm{~s}, 3 \mathrm{H}), 3.82(\mathrm{~s}, 3 \mathrm{H}), 5.01$ $(\mathrm{s}, 1 \mathrm{H}), 5.30(\mathrm{~s}, 1 \mathrm{H}), 6.88(\mathrm{~d}, J=8.8 \mathrm{~Hz}, 2 \mathrm{H}), 7.43(\mathrm{~d}, J=8.8 \mathrm{~Hz}$, $2 \mathrm{H}) .{ }^{13} \mathrm{C} \mathrm{NMR}\left(\mathrm{CDCl}_{3}\right), \delta: 21.9,55.2,110.6,113.5,126.6,133.7$, 142.5, 159.1 .

\section{Synthesis of sulfonylhydrazides $2 b-2 e$}

Following a literature procedure ${ }^{61}$ a THF $(20 \mathrm{~mL})$ solution containing the corresponding arylsulfonyl chloride (4-iodobenzenesulfonylchloride, 4-bromobenzenesulfonylchloride, 4-methoxybenzenesulfonylchloride, 4-nitrobenzenesulfonylchloride, 5.0 $\mathrm{g}, 16.5-24.2 \mathrm{mmol}$ ) was cooled using an ice-water bath to $5{ }^{\circ} \mathrm{C}$. Hydrazine hydrate $(64 \% \mathrm{w} / \mathrm{w}$ water solution of hydrazine, $2.1-$ $3.0 \mathrm{~g} ; 41.2-60.5 \mathrm{mmol}$ ) was slowly added with stirring. Then, the reaction mixture was stirred at $5{ }^{\circ} \mathrm{C}$ for $30 \mathrm{~min}$, diluted with THF $(20 \mathrm{~mL})$, washed with water $(3 \times 5 \mathrm{~mL})$ and dried over $\mathrm{Na}_{2} \mathrm{SO}_{4}$. The solvent was removed under reduced pressure (10-20 Torr) to give the pure products $2 \mathbf{b}-\mathbf{2 e}$.

4-Iodobenzenesulfonohydrazide $\quad(\mathbf{2 b}){ }^{67} \quad$ 4-Iodobenzenesulfonyl-chloride $(5.0 \mathrm{~g}, 16.5 \mathrm{mmol})$ gave the title compound as a white solid (4.3 g, $14.5 \mathrm{mmol}, 88 \%) . \mathrm{Mp}=173.0-175.0^{\circ} \mathrm{C}$ (lit. ${ }^{67} \mathrm{mp}=162.0{ }^{\circ} \mathrm{C}$ ). ${ }^{1} \mathrm{H}$ NMR (DMSO-d ${ }_{6}$ ), $\delta: 4.16$ (br s, 2H), 7.56 $(\mathrm{d}, J=8.4 \mathrm{~Hz}, 2 \mathrm{H}), 7.98(\mathrm{~d}, J=8.9 \mathrm{~Hz}, 2 \mathrm{H}), 8.46(\mathrm{~s}, 1 \mathrm{H}) .{ }^{13} \mathrm{C} \mathrm{NMR}$ $\left(\mathrm{DMSO}-\mathrm{d}_{6}\right), \quad \delta: 100.7,129.4,137.8,137.9$. Calculated for 
$\mathrm{C}_{6} \mathrm{H}_{7} \mathrm{IN}_{2} \mathrm{O}_{2} \mathrm{~S}$ C: $24.17 \%, \mathrm{H}: 2.37 \%$, I: $42.57 \%, \mathrm{~N}: 9.40 \%, \mathrm{~S}:$ 10.76\%. Found C: $24.23 \%, \mathrm{H}: 2.45 \%$, I: $42.18 \%$, N: $9.21 \%$, S: $10.57 \%$. HRMS (ESI) $\mathrm{m} / z[\mathrm{M}+\mathrm{Na}]^{+}$: calculated for $\left[\mathrm{C}_{6} \mathrm{H}_{7} \mathrm{IN}_{2}-\right.$ $\left.\mathrm{NaO}_{2} \mathrm{~S}\right]^{+}:$320.9171. Found: 320.9167. IR (KBr), $\nu, \mathrm{cm}^{-1}: 3366$, 3291, 1571, 1321, 1158, 1085, 1007, 933, 814, 737, 642, 556.

4-Bromobenzenesulfonohydrazide (2c). ${ }^{68}$ 4-Bromobenzenesulfonylchloride $(5.0 \mathrm{~g}, 19.6 \mathrm{mmol})$ gave the title compound as a white solid (4.5 g, $18.0 \mathrm{mmol}, 92 \%) . \mathrm{Mp}=114.0-116.0{ }^{\circ} \mathrm{C}$ (lit. $\left.{ }^{68} \mathrm{mp}=113.0-114.0{ }^{\circ} \mathrm{C}\right) .{ }^{1} \mathrm{H}$ NMR (DMSO-d 6 ), $\delta: 4.20$ (br s, $2 \mathrm{H}), 7.73(\mathrm{~d}, J=8.6 \mathrm{~Hz}, 2 \mathrm{H}), 7.80(\mathrm{~d}, J=8.6 \mathrm{~Hz}, 2 \mathrm{H}), 8.50(\mathrm{~s}, 1 \mathrm{H})$. ${ }^{13} \mathrm{C}$ NMR (DMSO-d $\mathrm{d}_{6}$ ), $\delta: 126.5,129.7,132.0,137.5$.

4-Methoxybenzenesulfonohydrazide $\quad$ (2d). ${ }^{69} \quad$ 4-Methoxybenzene-sulfonylchloride $(5.0 \mathrm{~g}, 24.2 \mathrm{mmol})$ gave the title compound as a white solid (4.6 g, $23.0 \mathrm{mmol}, 95 \%)$. White solid, $\mathrm{mp}=107.0-109.0{ }^{\circ} \mathrm{C}$ (lit. ${ }^{69} \mathrm{mp}=105.0-110.0{ }^{\circ} \mathrm{C}$ ). ${ }^{1} \mathrm{H} \mathrm{NMR}$ (DMSO-d ${ }_{6}$ ), $\delta: 3.83$ (s, 3H), $3.92($ br s, $1 \mathrm{H}), 7.12(\mathrm{~d}, J=8.8 \mathrm{~Hz}$, $2 \mathrm{H}), 7.74(\mathrm{~d}, J=8.8,2 \mathrm{H}), 8.21(\mathrm{~s}, 1 \mathrm{H}) .{ }^{13} \mathrm{C} \mathrm{NMR}\left(\mathrm{DMSO}_{6}\right), \delta$ : $55.7,114.2,129.5,129.8,162.4$.

4-Nitrobenzenesulfonohydrazide $\quad(2 \mathrm{e}) .^{69} \quad 4$-Nitrobenzenesulfonyl-chloride $(5.0 \mathrm{~g}, 22.6 \mathrm{mmol})$ gave the title compound as a yellow solid $(3.7 \mathrm{~g}, 16.9 \mathrm{mmol}, 75 \%) . \mathrm{Mp}=150.0-152.0{ }^{\circ} \mathrm{C}$ (lit. $\left.{ }^{69} \mathrm{mp}=152.0-157.0{ }^{\circ} \mathrm{C}\right) .{ }^{1} \mathrm{H}$ NMR (DMSO-d $\left.{ }_{6}\right): \delta 4.34$ (br s, $2 \mathrm{H}), 8.05(\mathrm{~d}, J=8.9 \mathrm{~Hz}, 2 \mathrm{H}), 8.42(\mathrm{~d}, J=8.9 \mathrm{~Hz}, 2 \mathrm{H}), 8.75(\mathrm{~s}, 1 \mathrm{H})$. ${ }^{13}$ C NMR (DMSO-d $\left.\mathrm{d}_{6}\right): \delta 124.2,129.2,144.2,149.7$.

General procedure 1. Preparation of 3aa and 4aa. Optimization of the reaction conditions for oxysulfonylation of styrene 1a with sulfonylhydrazide 2a (Table 1)

To a solution of styrene $1 \mathrm{a}(300 \mathrm{mg}, 2.88 \mathrm{mmol})$ in $25 \mathrm{~mL}$ of $\left(\mathrm{CH}_{3} \mathrm{CN}-\mathrm{H}_{2} \mathrm{O}(5: 1), \mathrm{CH}_{3} \mathrm{CN}, \mathrm{THF}, \mathrm{THF}-\mathrm{H}_{2} \mathrm{O}(5: 1)\right), \mathrm{Cu}(\mathrm{I})$ salt (0.58-14.4 mmol, molar ratio $0.2-5 \mathrm{~mol}$ of salt $/ \mathrm{mol} \mathrm{1a)}$ and $p$ toluenesulfonylhydrazide $2 \mathrm{a}(537 \mathrm{mg}, 2.88 \mathrm{mmol}$, molar ratio 1 $\mathrm{mol} \mathrm{2a} / \mathrm{mol} \mathrm{1a)}$ were added. The mixture was stirred in the air or an oxygen atmosphere for $7 \mathrm{~h}$ at $40{ }^{\circ} \mathrm{C}$, for $7 \mathrm{~h}$ at $80^{\circ} \mathrm{C}$, then for $12 \mathrm{~h}$ at room temperature.

\section{Treatment of the reaction mixture containing 3aa and 4aa}

The solvent was removed under reduced pressure (10-20 Torr). The reaction residue was diluted with a mixture of solvents $\mathrm{PE} /$ $\mathrm{CHCl}_{3} / \mathrm{EA}$ in a volume ratio of $1 / 2 / 2(50 \mathrm{~mL})$ and then filtered from the precipitate using $\mathrm{SiO}_{2}(d=20 \mathrm{~mm}, h=80 \mathrm{~mm})$. The precipitate was washed with a mixture of solvents $\mathrm{PE} / \mathrm{CHCl}_{3} / \mathrm{EA}$ in a volume ratio of $1 / 2 / 2(3 \times 30 \mathrm{~mL})$. The combined organic phases were concentrated under reduced pressure (10-20 Torr). The yields of 3aa and 4aa were determined by ${ }^{1} \mathrm{H}$ NMR using 1,4-dinitrobenzene as an internal standard.

General procedure 2. Synthesis of $\beta$-hydroxysulfones 3aa-3ab and $\beta$-ketosulfones 4aa-4ab (Table 2)

To a solution of styrene 1a-1e (300 mg, 1.87-2.88 mmol) in 25 $\mathrm{mL}$ of $\mathrm{CH}_{3} \mathrm{CN}-\mathrm{H}_{2} \mathrm{O}(5: 1), \mathrm{CuBr}$ (3.74-5.76 mmol, molar ratio 2 mol $\mathrm{mol}^{-1}$ 1a-1e) and sulfonylhydrazide 2a-2b (1.87-2.88 mmol, molar ratio $1 \mathrm{~mol} 2 / \mathrm{mol} \mathbf{1 a}-\mathbf{1 e}$ ) were added. The mixture was stirred under an oxygen atmosphere for $7 \mathrm{~h}$ at $40{ }^{\circ} \mathrm{C}$, then for $12 \mathrm{~h}$ at room temperature. Then, the reaction mixture was treated as described above (General procedure 1). The yields of 3aa, 3ba, 3ca, 3da, 3ea, 3ab and 4aa, 4ba, 4ca, 4da, 4ea, 4ab were determined by ${ }^{1} \mathrm{H}$ NMR using 1,4-dinitrobenzene as an internal standard. The products 3aa, 3ba, 3ca, 3da, 3ea, 3ab and 4aa, 4ba, 4ca, 4da, 4ea, 4ab were isolated by chromatography on $\mathrm{SiO}_{2}$ with elution using PE-EA in a linear gradient of the latter from 10 to $40 \mathrm{vol} \%$.

General procedure 3. Synthesis of $\beta$-hydroxysulfones 3aa-3ab using $\mathrm{NaBH}_{4}$ (Table 2, yield in parentheses)

The reaction mixture was treated as described above (General procedure 1). Then, the residue was diluted with $10 \mathrm{~mL}$ of THF$\mathrm{MeOH}(1: 1)$ mixture and $\mathrm{NaBH}_{4}$ (molar ratio 3 mol mol ${ }^{-1}$ 4aa, 4ba, 4ca, 4da, 4ea, 4ab) was added with vigorous stirring. The mixture was stirred for $3 \mathrm{~h}$ at $0-5{ }^{\circ} \mathrm{C}$. The solvent was removed under reduced pressure (10-20 Torr). The residue was diluted with EA $(50 \mathrm{~mL})$ and washed with water $(2 \times 5 \mathrm{~mL})$, brine $(3 \times 5$ $\mathrm{mL})$ and again water $(2 \times 5 \mathrm{~mL})$, dried over $\mathrm{Na}_{2} \mathrm{SO}_{4}$ and concentrated under reduced pressure (10-20 Torr). The desired products 3aa, 3ba, 3ca, 3da, 3ea, 3ab were isolated by chromatography on $\mathrm{SiO}_{2}$ with elution using PE-EA in a linear gradient of the latter from 10 to $40 \mathrm{vol} \%$.

2-[(4-Methylphenyl)sulfonyl]-1-phenylethanol (3aa). ${ }^{70}$ White solid, $\mathrm{mp}=68.5-70.0^{\circ} \mathrm{C}\left(\right.$ lit. $\left.^{70} \mathrm{mp}=68.5-69.5^{\circ} \mathrm{C}\right)$. Yield $85 \% . R_{\mathrm{f}}$ $=0.26$ (TLC, PE : EA, $5: 1) .{ }^{1} \mathrm{H}$ NMR $\left(\mathrm{CDCl}_{3}\right), \delta: 2.45(\mathrm{~s}, 3 \mathrm{H}$, $\mathrm{CH}_{3}$ ), 3.31 (dd, $\left.J=14.3,1.8 \mathrm{~Hz}, 1 \mathrm{H}\right), 3.47(\mathrm{dd}, J=10.0,14.3 \mathrm{~Hz}$, $1 \mathrm{H}), 3.76(\mathrm{~d}, J=2.0 \mathrm{~Hz}, 1 \mathrm{H}), 5.23$ (ddd, $J=10.3,2.0,1.8 \mathrm{~Hz}, 1 \mathrm{H}$ ), $7.23-7.32(\mathrm{~m}, 5 \mathrm{H}), 7.37$ (d, $J=8.1 \mathrm{~Hz}, 2 \mathrm{H}), 7.82(\mathrm{~d}, J=8.1 \mathrm{~Hz}$, 2H). ${ }^{13} \mathrm{C} \mathrm{NMR}\left(\mathrm{CDCl}_{3}\right), \delta: 21.6,63.9,68.4,125.6,127.9,128.2$, 128.6, 130.0, 136.1, 140.7, 145.1. Calculated for $\mathrm{C}_{15} \mathrm{H}_{16} \mathrm{O}_{3} \mathrm{~S}$ C: 65.19\%, H: 5.84\%, S: $11.60 \%$. Found C: $65.12 \%$, H: $5.78 \%$, S: $11.66 \%$. HRMS (ESI) $\mathrm{m} / \mathrm{z}[\mathrm{M}+\mathrm{Na}]^{+}$: calculated for $\left[\mathrm{C}_{15} \mathrm{H}_{16} \mathrm{NaO}_{3} \mathrm{~S}\right]^{+}$: 299.0718. Found: 299.0712. IR (KBr), $\nu, \mathrm{cm}^{-1}$ : 3496, 1391, 1286, 1167, 1137, 1087, 1064, 1020, 998, 834, 818, 779, 747, 706, 640, 555, 537, 514, 500, 462.

1-(2-Methylphenyl)-2-[(4-methylphenyl)sulfonyl] ethanol (3ba) ${ }^{70}$ White solid, $\mathrm{mp}=118.0-120.0{ }^{\circ} \mathrm{C}$ (lit. ${ }^{70} \mathrm{mp}=116.1-118.0{ }^{\circ} \mathrm{C}$ ). Yield 54\%. $R_{\mathrm{f}}=0.34$ (TLC, PE : EA, $\left.3: 1\right) .{ }^{1} \mathrm{H} \mathrm{NMR}\left(\mathrm{CDCl}_{3}\right), \delta: 2.08$ (s, 3H), $2.46(\mathrm{~s}, 3 \mathrm{H}), 3.22(\mathrm{dd}, J=14.5,1.3 \mathrm{~Hz}, 1 \mathrm{H}), 3.39(\mathrm{dd}, J=$ 14.5, $9.8 \mathrm{~Hz}, 1 \mathrm{H}), 3.69$ (s, 1H), 5.42 (d, $J=9.8 \mathrm{~Hz}, 1 \mathrm{H}), 7.07$ (dd, $J=$ 7.2, $2.0 \mathrm{~Hz}, 1 \mathrm{H}), 7,11-7.24(\mathrm{~m}, 2 \mathrm{H}), 7.38(\mathrm{~d}, J=8.1 \mathrm{~Hz}, 2 \mathrm{H}), 7.48$ (dd, $J=7.2,1.7 \mathrm{~Hz}, 1 \mathrm{H}), 7.85(\mathrm{~d}, J=8.1 \mathrm{~Hz}, 2 \mathrm{H}) .{ }^{13} \mathrm{C} \mathrm{NMR}\left(\mathrm{CDCl}_{3}\right)$, $\delta$ : 18.5, 21.6, 62.9, 65.0, 125.2, 126.5, 127.9, 128.0, 130.0, 130.5, 133.6, 136.0, 138.7, 145.2. Calculated for $\mathrm{C}_{16} \mathrm{H}_{18} \mathrm{O}_{3} \mathrm{~S}$ C: $66.18 \%, \mathrm{H}$ : 6.25\%, S: $11.04 \%$. Found C: $66.15 \%$, H: 6.21\%, S: $10.89 \%$. HRMS (ESI) $\mathrm{m} / z[\mathrm{M}+\mathrm{Na}]^{+}$: calculated for $\left[\mathrm{C}_{16} \mathrm{H}_{18} \mathrm{NaO}_{3} \mathrm{~S}\right]^{+}: 313.0874$. Found: 313.0869. IR (KBr), $\nu, \mathrm{cm}^{-1}$ : 3517, 1299, 1287, 1247, 1236, 1199, 1189, 1170, 1158, 1142, 1086, 1047, 857, 803, 758, 749, 721, 638, 564, 518, 506, 456.

1-(4-Isopropylphenyl)-2-[(4-methylphenyl)sulfonyl]ethanol (3ca). White solid, $\mathrm{mp}=92.5-95.0{ }^{\circ} \mathrm{C}$. Yield $72 \% . R_{\mathrm{f}}=0.39$ (TLC, PE : EA, $3: 1) .{ }^{1} \mathrm{H}$ NMR (DMSO-d ${ }_{6}$ ), $\delta: 1.16(\mathrm{~d}, J=6.9 \mathrm{~Hz}$, $6 \mathrm{H}), 2.39(\mathrm{~s}, 3 \mathrm{H}), 2.83(\mathrm{~m}, J=6.9 \mathrm{~Hz}, 1 \mathrm{H}), 3.50(\mathrm{dd}, J=14.5$, $3.7 \mathrm{~Hz}, 1 \mathrm{H}), 3.67$ (dd, $J=14.5,8.5 \mathrm{~Hz}, 1 \mathrm{H}), 4.96(\mathrm{ddd}, J=8.5$, $4.7,3.7 \mathrm{~Hz}, 1 \mathrm{H}), 5.52(\mathrm{~d}, J=4.7 \mathrm{~Hz}, 1 \mathrm{H}), 7.13(\mathrm{~d}, J=8.2 \mathrm{~Hz}$, $2 \mathrm{H}), 7.20(\mathrm{~d}, J=8.2 \mathrm{~Hz}, 2 \mathrm{H}), 7.38(\mathrm{~d}, J=8.2 \mathrm{~Hz}, 2 \mathrm{H}), 7.75(\mathrm{~d}, J$ $=8.2 \mathrm{~Hz}, 2 \mathrm{H}) .{ }^{13} \mathrm{C}$ NMR $\left(\mathrm{DMSO}^{-\mathrm{d}_{6}}\right), \delta: 21.0,23.9,33.1,63.0$, 
67.8, 126.0, 126.1, 127.8, 129.4, 137.6, 140.5, 143.7, 147.6. Calculated for $\mathrm{C}_{18} \mathrm{H}_{22} \mathrm{O}_{3} \mathrm{~S}$ C: $67.89 \%, \mathrm{H}: 6.96 \%$, S: $10.07 \%$. Found C: $67.87 \%$, H: 7.01\%, S: 10.14\%. HRMS (ESI) $m / z$ [M + $\mathrm{Na}]^{+}$: calculated for $\left[\mathrm{C}_{18} \mathrm{H}_{22} \mathrm{NaO}_{3} \mathrm{~S}\right]^{+}:$341.1187. Found: 341.1178. IR (KBr), $\nu, \mathrm{cm}^{-1}$ : 3500, 2966, 1410, 1302, 1287, 1253, 1170, 1140, 1086, 1052, 1001, 862, 851, 822, 776, 734, 635, 597, 568, 547, 532, 509, 471, 449.

1-(4-tert-Butylphenyl)-2-[(4-methylphenyl)sulfonyl]ethanol (3da). White solid, $\mathrm{mp}=106.0-107.0{ }^{\circ} \mathrm{C}$. Yield 89\%. $R_{\mathrm{f}}=0.40$ (TLC, PE : EA, $3: 1) .{ }^{1} \mathrm{H}$ NMR (DMSO-d ${ }_{6}$ ), $\delta: 1.24$ (s, 9H), 2.39 $(\mathrm{s}, 3 \mathrm{H}), 3.50(\mathrm{dd}, J=14.6,3.8 \mathrm{~Hz}, 1 \mathrm{H}), 3.67(\mathrm{dd}, J=14.6,8.5$ $\mathrm{Hz}, 1 \mathrm{H}), 4.96$ (ddd, $J=8.5,4.7,3.8 \mathrm{~Hz}, 1 \mathrm{H}), 5.52(\mathrm{~d}, J=4.7 \mathrm{~Hz}$, $1 \mathrm{H}), 7.20$ (d, $J=8.2 \mathrm{~Hz}, 2 \mathrm{H}), 7.28$ (d, $J=8.2 \mathrm{~Hz}, 2 \mathrm{H}), 7.37$ (d, $J$ $=8.1 \mathrm{~Hz}, 2 \mathrm{H}), 7.75(\mathrm{~d}, J=8.1 \mathrm{~Hz}, 2 \mathrm{H}) .{ }^{13} \mathrm{C} \mathrm{NMR}\left(\mathrm{DMSO}_{6}\right), \delta$ : 21.0, 31.1, 34.1, 62.9, 67.7, 124.8, 125.8, 127.7, 129.4, 137.6, 140.0, 143.6, 149.8. Calculated for $\mathrm{C}_{19} \mathrm{H}_{24} \mathrm{O}_{3} \mathrm{~S}$ C: $68.64 \%, \mathrm{H}$ : 7.28\%, S: 9.64\%. Found C: 68.57\%, H: 6.94\%, S: 9.51\%. HRMS (ESI) $m / z[\mathrm{M}+\mathrm{Na}]^{+}$: calculated for $\left[\mathrm{C}_{19} \mathrm{H}_{24} \mathrm{NaO}_{3} \mathrm{~S}\right]^{+}: 313.0874$. Found: 313.0869. IR (KBr), $\nu, \mathrm{cm}^{-1}$ : 3521, 2962, 1303, 1289, 1242, 1174, 1140, 1113, 1087, 1057, 864, 844, 823, 773, 737, 636, 579, 543, 528, 506.

1-(4-Chlorophenyl)-2-[(4-methylphenyl)sulfonyl] ethanol (3ea) ${ }^{70}$ White solid, $\mathrm{mp}=89.5-92.5{ }^{\circ} \mathrm{C}$ (lit. ${ }^{70} \mathrm{mp}=88.0-91.0{ }^{\circ} \mathrm{C}$ ). Yield $52 \% . R_{\mathrm{f}}=0.28(\mathrm{TLC}, \mathrm{PE}: \mathrm{EA}, 3: 1) .{ }^{1} \mathrm{H}$ NMR $\left(\mathrm{DMSO}_{6}\right), \delta: 2.40(\mathrm{~s}$, $3 \mathrm{H}), 3.55(\mathrm{dd}, J=14.6,4.0 \mathrm{~Hz}, 1 \mathrm{H}), 3.67(\mathrm{dd}, J=14.6,8.2 \mathrm{~Hz}, 1 \mathrm{H})$, 4.97 (ddd, $J=8.2,5.0,4.0 \mathrm{~Hz}, 1 \mathrm{H}), 5.70(\mathrm{~d}, J=5.0 \mathrm{~Hz}, 1 \mathrm{H}), 7.32$ (s, $4 \mathrm{H}), 7.39$ (d, $J=8.1 \mathrm{~Hz}, 1 \mathrm{H}), 7.75$ (d, $J=8.1 \mathrm{~Hz}, 1 \mathrm{H}) .{ }^{13} \mathrm{C}$ NMR (DMSO-d ${ }_{6}$ ), $\delta: 21.0,62.6,67.3,127.8,128.0,128.1,129.4,131.9$, 137.5, 141.9, 143.8. Calculated for $\mathrm{C}_{15} \mathrm{H}_{15} \mathrm{ClO}_{3} \mathrm{~S}$ C: $57.97 \%, \mathrm{H}$ : 4.86\%, Cl: $11.41 \%$, S: $10.32 \%$. Found C: $57.95 \%$, H: $4.93 \%$, Cl: 11.34\%, S: $10.25 \%$. HRMS (ESI) $m / z[\mathrm{M}+\mathrm{Na}]^{+}$: calculated for: $\left[\mathrm{C}_{15} \mathrm{H}_{15} \mathrm{ClNaO}_{3} \mathrm{~S}\right]^{+}:$333.0328. Found: 333.0323. IR (KBr), $\nu, \mathrm{cm}^{-1}$ : 3485, 1311, 1300, 1287, 1160, 1145, 1138, 1087, 1076, 1064, 1013, $813,714,562,511,502$.

2-[(4-Iodophenyl)sulfonyl]-1-phenylethanol (3ab). White solid, $\mathrm{mp}=108.0-112.0{ }^{\circ} \mathrm{C}$. Yield $62 \% . R_{\mathrm{f}}=0.32$ (TLC, PE : EA, $5: 1) .{ }^{1} \mathrm{H}$ NMR (DMSO-d ${ }_{6}$ ), $\delta: 3.55$ (dd, $\left.J=14.6,3.3 \mathrm{~Hz}, 1 \mathrm{H}\right), 3.76$ (dd, $J=14.6,9.2 \mathrm{~Hz}, 1 \mathrm{H}), 5.00(\mathrm{ddd}, J=9.2,4.8,3.3 \mathrm{~Hz}, 1 \mathrm{H}), 5.62$ (d, $J=4.8 \mathrm{~Hz}, 1 \mathrm{H}), 7.19-7.34(\mathrm{~m}, 5 \mathrm{H}), 7.65(\mathrm{~d}, J=8.4 \mathrm{~Hz}, 2 \mathrm{H})$, $7.99(\mathrm{~d}, J=8.4 \mathrm{~Hz}, 2 \mathrm{H}) .{ }^{13} \mathrm{C}$ NMR $\left(\mathrm{DMSO}^{-} \mathrm{d}_{6}\right), \delta: 62.6,67.9,101.9$, 126.1, 127.4, 128.2, 129.5, 137.8, 140.3, 142.9. Calculated for $\mathrm{C}_{14} \mathrm{H}_{13} \mathrm{IO}_{3} \mathrm{~S} \mathrm{C}: 43.31 \%$, H: $3.38 \%$, I: $32.69 \%$, S: $8.26 \%$. Found C: 43.28\%, H: $3.31 \%$, I: $32.32 \%$, S: $8.09 \%$. HRMS (ESI) $m / z[\mathrm{M}+$ $\mathrm{Na}]^{+}$: calculated for $\left[\mathrm{C}_{14} \mathrm{H}_{13} \mathrm{INaO}_{3} \mathrm{~S}\right]^{+}:$410.9528. Found: 410.9522. IR (KBr), $\nu, \mathrm{cm}^{-1}: 3464,1384,1303,1270,1135,1083$, 1061, 1003, 993, 817, 745, 701, 566, 549, 531.

2-[(4-Methylphenyl)sulfonyl]-1-phenylethanone

(4aa)..$^{71}$ White solid, $\mathrm{mp}=102.5-104.5{ }^{\circ} \mathrm{C}$ (lit. $\left.{ }^{71} \mathrm{mp}=102.0-103.0{ }^{\circ} \mathrm{C}\right)$. Yield 36\%. $R_{\mathrm{f}}=0.73$ (TLC, PE : EA, $\left.2: 1\right) .{ }^{1} \mathrm{H}$ NMR $\left(\mathrm{CDCl}_{3}\right), \delta$ : $2.43(\mathrm{~s}, 3 \mathrm{H}), 4.73(\mathrm{~s}, 2 \mathrm{H}), 7.32(\mathrm{~d}, J=8.2 \mathrm{~Hz}, 2 \mathrm{H}), 7.46(\mathrm{dd}, J=$ $7.5,7.3 \mathrm{~Hz}, 2 \mathrm{H}), 7.61(\mathrm{t}, J=7.5 \mathrm{~Hz}, 1 \mathrm{H}), 7.77(\mathrm{~d}, J=8.2 \mathrm{~Hz}, 2 \mathrm{H})$, $7.94(\mathrm{~d}, J=7.3 \mathrm{~Hz}, 2 \mathrm{H}) .{ }^{13} \mathrm{C} \mathrm{NMR}\left(\mathrm{CDCl}_{3}\right), \delta: 21.6,63.5,128.5$, 128.7, 129.2, 129.7, 134.2, 135.7, 135.8, 145.2, 188.1. Calculated for $\mathrm{C}_{15} \mathrm{H}_{14} \mathrm{O}_{3} \mathrm{~S}$ C: $65.67 \%, \mathrm{H}$ : $5.14 \%, \mathrm{~S}: 11.69 \%$. Found $\mathrm{C}$ : 65.57\%, H: 5.34\%, S: 11.59\%. HRMS (ESI) $m / z[\mathrm{M}+\mathrm{Na}]^{+}$: calculated for $\left[\mathrm{C}_{15} \mathrm{H}_{14} \mathrm{NaO}_{3} \mathrm{~S}\right]^{+}:$297.0561. Found: 297.0556. IR
(KBr), $\nu, \mathrm{cm}^{-1}:$ 1680, 1596, 1320, 1271, 1150, 1087, 993, 750, 739, 686, 590, 535, 503.

1-(2-Methylphenyl)-2-[(4-methylphenyl)sulfonyl]ethanone (4ba). ${ }^{72}$. White solid, $\mathrm{mp}=108-110{ }^{\circ} \mathrm{C}\left(\right.$ lit. $\left.^{72} \mathrm{mp}=109-111^{\circ} \mathrm{C}\right)$. Yield 18\%. $R_{\mathrm{f}}=0.37$ (TLC, PE : EA, $\left.3: 1\right) .{ }^{1} \mathrm{H}$ NMR $\left(\mathrm{CDCl}_{3}\right), \delta$ : $2.45(\mathrm{~s}, 6 \mathrm{H}), 4.70(\mathrm{~s}, 2 \mathrm{H}), 7.23-7.31(\mathrm{~m}, 2 \mathrm{H}), 7.31-7.36(\mathrm{~m}, 2 \mathrm{H})$, 7.39-7.46 (m, 1H), 7.71-7.79 (m, 3H). ${ }^{13} \mathrm{C} \mathrm{NMR}\left(\mathrm{CDCl}_{3}\right), \delta: 21.4$, 21.6, 65.5, 125.8, 128.4, 129.7, 130.3, 132.2, 132.7, 135.7, 136.0, 139.9, 145.1, 190.5. Calculated for $\mathrm{C}_{16} \mathrm{H}_{16} \mathrm{O}_{3} \mathrm{~S}$ C: $66.64 \%, \mathrm{H}$ : 5.59\%, S: $11.12 \%$. Found C: $66.38 \%, \mathrm{H}: 5.80 \%$, S: $11.29 \%$. HRMS (ESI) $m / z[\mathrm{M}+\mathrm{Na}]^{+}$: calculated for $\left[\mathrm{C}_{16} \mathrm{H}_{16} \mathrm{NaO}_{3} \mathrm{~S}\right]^{+}$: 311.0718. Found: 311.0714. IR (KBr), $\nu, \mathrm{cm}^{-1}:$ 2956, 2910, 1685, 1314, 1291, 1142, 1084, 978, 823, 761, 747, 556, 517.

1-(4-Isopropylphenyl)-2-[(4-methylphenyl)sulfonyl] ethanone (4ca). White solid, $\mathrm{mp}=127.0-129.5{ }^{\circ} \mathrm{C}$. Yield $23 \% . R_{\mathrm{f}}=0.43$ (TLC, PE : EA, $3: 1) .{ }^{1} \mathrm{H} \mathrm{NMR}\left(\mathrm{CDCl}_{3}\right), \delta: 1.26(\mathrm{~d}, J=7.0 \mathrm{~Hz}, 6 \mathrm{H})$, $2.43(\mathrm{~s}, 3 \mathrm{H}), 2.97(\mathrm{~m}, J=7.0 \mathrm{~Hz}, 1 \mathrm{H}), 4.69(\mathrm{~s}, 2 \mathrm{H}), 7.32(2 \mathrm{~d}, J=$ $8.2,8.4 \mathrm{~Hz}, 4 \mathrm{H}), 7.76(\mathrm{~d}, J=8.2 \mathrm{~Hz}, 2 \mathrm{H}), 7.87(\mathrm{~d}, J=8.4 \mathrm{~Hz}, 2 \mathrm{H})$. ${ }^{13} \mathrm{C}$ NMR $\left(\mathrm{CDCl}_{3}\right), \delta: 21.6,23.5,34.3,63.5,126.9,128.6,129.6$, $129.7,133.7,135.8,145.2,156.1,187.6$. Calculated for $\mathrm{C}_{18} \mathrm{H}_{20} \mathrm{O}_{3} \mathrm{~S}$ C: $68.33 \%$, H: $6.37 \%$, S: $10.13 \%$. Found C: $67.86 \%$, $\mathrm{H}: 6.82 \%$, S: $9.70 \%$. HRMS (ESI) $m / z[\mathrm{M}+\mathrm{Na}]^{+}$: calculated for $\left[\mathrm{C}_{18} \mathrm{H}_{20} \mathrm{NaO}_{3} \mathrm{~S}\right]^{+}$: 339.1031. Found: 339.1025. IR (KBr), $\nu, \mathrm{cm}^{-1}$ : 2953, 1686, 1311, 1290, 1183, 1142, 1084, 828, 549.

1-(4-tert-Butylphenyl)-2-[(4-methylphenyl)sulfonyl]ethanone (4da). White solid, $\mathrm{mp}=98.5-101.0^{\circ} \mathrm{C}$. Yield 31\%. $R_{\mathrm{f}}=0.49$ (TLC, PE : EA, $3: 1) .{ }^{1} \mathrm{H}$ NMR $\left(\mathrm{CDCl}_{3}\right), \delta: 1.34(\mathrm{~s}, 9 \mathrm{H}), 2.44(\mathrm{~s}$, $3 \mathrm{H}), 4.69(\mathrm{~s}, 2 \mathrm{H}), 7.32(\mathrm{~d}, J=7.9 \mathrm{~Hz}, 2 \mathrm{H}), 7.48(\mathrm{~d}, J=8.2 \mathrm{~Hz}, 2 \mathrm{H})$, $7.76(\mathrm{~d}, J=7.9 \mathrm{~Hz}, 2 \mathrm{H}), 7.88$ (d, $J=8.2 \mathrm{~Hz}, 2 \mathrm{H}) .{ }^{13} \mathrm{C}$ NMR $\left(\mathrm{CDCl}_{3}\right), \delta: 21.7,31.0,35.2,63.6,125.8,128.6,129.3,129.8$, 133.3, 135.9, 145.2, 158.3, 187.6. Calculated for $\mathrm{C}_{19} \mathrm{H}_{22} \mathrm{O}_{3} \mathrm{~S}$ C: 69.06\%, H: 6.71\%, S: 9.70\%. Found C: $69.01 \%$, H: $6.65 \%$, S: 9.59\%. HRMS (ESI) $m / z \quad[\mathrm{M}+\mathrm{Na}]^{+}$: calculated for $\left[\mathrm{C}_{19} \mathrm{H}_{22} \mathrm{NaO}_{3} \mathrm{~S}\right]^{+}$: 353.1187. Found: 353.1182. IR (KBr), $\nu, \mathrm{cm}^{-1}$ : 1681, 1314, 1290, 1141, 1083, 828, 768, 590, 549, 516.

1-(4-Chlorophenyl)-2-[(4-methylphenyl)sulfonyl $]$ ethanone (4ea). ${ }^{71}$. White solid, $\mathrm{mp}=128.0-130.5{ }^{\circ} \mathrm{C}$ (lit. ${ }^{71} \mathrm{mp}=137.0-$ $138.0{ }^{\circ} \mathrm{C}$ ). Yield $24 \% . R_{\mathrm{f}}=0.46$ (TLC, PE : EA, $3: 1$ ). ${ }^{1} \mathrm{H}$ NMR $\left(\mathrm{CDCl}_{3}\right), \delta: 2.45(\mathrm{~s}, 3 \mathrm{H}), 4.68(\mathrm{~s}, 2 \mathrm{H}), 7.34(\mathrm{~d}, J=8.2 \mathrm{~Hz}, 2 \mathrm{H}), 7.45$ $(\mathrm{d}, J=8.6 \mathrm{~Hz}, 2 \mathrm{H}), 7.74(\mathrm{~d}, J=8.2 \mathrm{~Hz}, 2 \mathrm{H}), 7.90(\mathrm{~d}, J=8.6 \mathrm{~Hz}$, 2H). ${ }^{13} \mathrm{C} \mathrm{NMR}\left(\mathrm{CDCl}_{3}\right), \delta: 21.7,63.7,128.5,129.2,129.9,130.7$, 134.1, 135.6, 141.0, 145.5, 187.0. Calculated for $\mathrm{C}_{15} \mathrm{H}_{13} \mathrm{ClO}_{3} \mathrm{~S} \mathrm{C}$ : 58.35\%, H: 4.24\%, Cl: $11.48 \%$, S: $10.38 \%$. Found C: $58.37 \%$, H: 4.31\%, Cl: $10.98 \%$, S: 9.93\%. HRMS (ESI) $m / z[\mathrm{M}+\mathrm{Na}]^{+}:$calculated for $\left[\mathrm{C}_{15} \mathrm{H}_{13} \mathrm{ClNaO}_{3} \mathrm{~S}\right]^{+}$: 331.0172. Found: 331.0166. IR (KBr), $\nu, \mathrm{cm}^{-1}:$ 1679, 1589, 1315, 1290, 1277, 1148, 1091, 1083, 1004, 784, 759, 724, 537, 507.

2-[(4-Iodophenyl)sulfonyl]-1-phenylethanone (4ab). White solid, $\mathrm{mp}=125.0-127.0{ }^{\circ} \mathrm{C}$. Yield $25 \% . R_{\mathrm{f}}=0.38$ (TLC, PE : EA, 5 : 1). ${ }^{1} \mathrm{H} \mathrm{NMR}\left(\mathrm{CDCl}_{3}\right), \delta: 4.73(\mathrm{~s}, 2 \mathrm{H}), 7.49(\mathrm{t}, J=7.2 \mathrm{~Hz}, 2 \mathrm{H})$, $7.56-7.68(\mathrm{~m}, 3 \mathrm{H}), 7.87-7.95(\mathrm{~m}, 4 \mathrm{H}) .{ }^{13} \mathrm{C} \mathrm{NMR}\left(\mathrm{CDCl}_{3}\right), \delta: 63.2$, $102.5,128.9,129.2$, 129.9, 134.5, 135.5, 138.3, 138.4, 187.8 . Calculated for $\mathrm{C}_{14} \mathrm{H}_{11} \mathrm{IO}_{3} \mathrm{~S}$ C: $43.54 \%, \mathrm{H}: 2.87 \%$, I: $32.86 \%$, S: 8.30\%. Found C: $43.58 \%$, H: 3.01\%, I: 32.65\%, S: 8.25\%. HRMS (ESI) $m / z[\mathrm{M}+\mathrm{Na}]^{+}$: calculated for $\left[\mathrm{C}_{14} \mathrm{H}_{11} \mathrm{INaO}_{3} \mathrm{~S}\right]^{+}: 408.9371$. Found: 408.9366. IR (KBr), $\nu, \mathrm{cm}^{-1}$ : 1677, 1563, 1379, 1314, 1273, 1151, 1002, 756, 741, 727, 565, 516. 
General procedure 4. Synthesis of $\beta$-hydroxysulfones $3 \mathrm{fa}-3 \mathrm{fe}$ (Table 3)

To a solution of styrene $\mathbf{1 f}-\mathbf{1 j}$ (300 $\mathrm{mg}, 1.52-2.54 \mathrm{mmol}$ ) in 25 $\mathrm{mL}$ of $\mathrm{CH}_{3} \mathrm{CN}-\mathrm{H}_{2} \mathrm{O}(5: 1)$, $\mathrm{CuBr}$ (3.04-5.08 mmol, molar ratio 2 mol mol $\left.{ }^{-1} \mathbf{1 f}-\mathbf{1 j}\right)$ and sulfonylhydrazide $2 \mathrm{a}-2 \mathrm{e}(1.52-2.54 \mathrm{mmol}$, molar ratio $1 \mathrm{~mol} \mathbf{2} / \mathrm{mol} \mathbf{1} \mathbf{f}-\mathbf{1 j}$ ) were added. The mixture was stirred under an oxygen atmosphere for $7 \mathrm{~h}$ at $40{ }^{\circ} \mathrm{C}$, then for 12 $\mathrm{h}$ at room temperature. Then, the reaction mixture was treated as described above (General procedure 1). The desired products 3fa, 3ga, 3ha, 3ia, 3ja, 3fc, 3fd, 3fe were isolated by chromatography on $\mathrm{SiO}_{2}$ with elution using $\mathrm{PE}-\mathrm{EA}$ in a linear gradient of the latter from 10 to $40 \mathrm{vol} \%$.

1-[(4-Methylphenyl)sulfonyl]-2-phenylpropan-2-ol $\quad$ (3fa). ${ }^{73}$ White solid, $\mathrm{mp}=99.5-100.5{ }^{\circ} \mathrm{C}$ (lit. ${ }^{73} \mathrm{mp}=103-104{ }^{\circ} \mathrm{C}$ ). Yield $92 \% . R_{\mathrm{f}}=0.64$ (TLC, PE : EA, $\left.2: 1\right) .{ }^{1} \mathrm{H}$ NMR $\left(\mathrm{CDCl}_{3}\right), \delta: 1.71(\mathrm{~d}, J$ $=1.1 \mathrm{~Hz}, 3 \mathrm{H}), 2.39(\mathrm{~s}, 3 \mathrm{H}), 3.61(\mathrm{dd}, J=14.6,1.1 \mathrm{~Hz}, 1 \mathrm{H}), 3.72$ (d, $J=14.6,1.1 \mathrm{~Hz}, 1 \mathrm{H}), 4.66$ (br s, $1 \mathrm{H}), 7.14-7.24$ (m, 5H), 7.26$7.34(\mathrm{~m}, 2 \mathrm{H}), 7.49(\mathrm{dd}, J=8.2,1.0 \mathrm{~Hz}, 2 \mathrm{H}) .{ }^{13} \mathrm{C} \mathrm{NMR}\left(\mathrm{CDCl}_{3}\right), \delta$ : 21.5, 30.7, 66.6, 73.0, 124.5, 127.0, 127.4, 128.1, 129.6, 137.3, 144.4. Calculated for $\mathrm{C}_{16} \mathrm{H}_{18} \mathrm{O}_{3} \mathrm{~S}$ C: $66.18 \%$, H: $6.25 \%$, S: $11.04 \%$. Found C: $66.23 \%, \mathrm{H}: 6.06 \%$, S: $11.12 \%$. HRMS (ESI) $m / z[\mathrm{M}+$ $\mathrm{Na}]^{+}$: calculated for $\left[\mathrm{C}_{16} \mathrm{H}_{18} \mathrm{NaO}_{3} \mathrm{~S}\right]^{+}: 313.0874$. Found: 313.0879 . IR (KBr), $\nu, \mathrm{cm}^{-1}: 3500,2973,1451,1355,1300,1268,1247$, 1182, 1155, 1119, 1081, 1036, 1024, 1017, 947, 858, 813, 767, 707, 637, 570, 555, 532, 509, 477.

2-(4-Chlorophenyl)-1-[(4-methylphenyl)sulfonyl]propan-2-ol (3ga). White solid, $\mathrm{mp}=142-144{ }^{\circ} \mathrm{C}$. Yield 90\%. $R_{\mathrm{f}}=0.68$ (TLC, PE : EA, 2 : 1). ${ }^{1} \mathrm{H}$ NMR $\left(\mathrm{CDCl}_{3}\right), \delta: 1.62(\mathrm{~s}, 3 \mathrm{H}), 2.39(\mathrm{~s}, 3 \mathrm{H}), 3.55$ $(\mathrm{d}, J=14.8 \mathrm{~Hz}, 1 \mathrm{H}), 3.69$ (d, $J=14.8 \mathrm{~Hz}, 1 \mathrm{H}), 7.07(\mathrm{~d}, J=8.7 \mathrm{~Hz}$, 2H) $7.15(\mathrm{~d}, J=8.7 \mathrm{~Hz}, 2 \mathrm{H}) 7.15(\mathrm{~d}, J=8.3 \mathrm{~Hz}, 2 \mathrm{H}), 7.41$ (d, $J=$ 8.3 Hz, 2H). ${ }^{13} \mathrm{C} \mathrm{NMR}\left(\mathrm{CDCl}_{3}\right), \delta: 21.5,30.9,66.3,72.7,126.2$, $127.5,128.2$, 129.7, 133.1, 137.0, 142.8, 144.7. Calculated for $\mathrm{C}_{16} \mathrm{H}_{17} \mathrm{ClO}_{3} \mathrm{~S}$ C: $59.16 \%, \mathrm{H}: 5.28 \%$, Cl: $10.91 \%$, S: $9.87 \%$. Found C: $58.99 \%$, H: $5.29 \%$, Cl: $11.04 \%$, S: 9.98\%. HRMS (ESI) $m / z[\mathrm{M}+$ $\mathrm{Na}]^{+}$: calculated for $\left[\mathrm{C}_{16} \mathrm{H}_{17} \mathrm{ClNaO}_{3} \mathrm{~S}\right]^{+}:$347.0485. Found: 347.0479. IR (KBr), $\nu, \mathrm{cm}^{-1}$ : 3496, 1308, 1302, 1252, 1158, 1128, 1082, 1044, 849, 771, 645, 543, 522, 460.

2-(4-Bromophenyl)-1-[(4-methylphenyl)sulfonyl]propan-2-ol (3ha). ${ }^{16}$. Light-brown solid, $\mathrm{mp}=160.5-163{ }^{\circ} \mathrm{C}$ (lit. ${ }^{16} \mathrm{mp}=$ 164.0-166.0 ${ }^{\circ} \mathrm{C}$ ). Yield 93\%. $R_{\mathrm{f}}=0.29(\mathrm{TLC}, \mathrm{PE}: \mathrm{EA}, 3: 1) .{ }^{1} \mathrm{H}$ NMR (DMSO-d ${ }_{6}$ ), $\delta: 1.55$ (s, 3H), $2.37(\mathrm{~s}, 3 \mathrm{H}), 3.77(\mathrm{~d}, J=14.8 \mathrm{~Hz}$, $1 \mathrm{H}), 3.84(\mathrm{~d}, J=14.8 \mathrm{~Hz}, 1 \mathrm{H}), 7.24-7.35(\mathrm{~m}, 6 \mathrm{H}), 7.52(\mathrm{~d}, J=8.0$ $\mathrm{Hz}, 2 \mathrm{H}) .{ }^{13} \mathrm{C}$ NMR (DMSO-d 6 ), $\delta: 21.0,30.0,66.0,71.5,119.8$, $127.5,127.6,129.2,130.3,138.2,143.4,145.4$. Calculated for $\mathrm{C}_{16} \mathrm{H}_{17} \mathrm{BrO}_{3} \mathrm{~S}$ C: $52.04 \%, \mathrm{H}: 4.64 \%$, Br: $21.64 \%$, S: $8.68 \%$. Found C: $52.14 \%$, H: $4.73 \%$, Br: 21.12\%, S: 8.47\%. HRMS (ESI) $m / z$ [M + $\mathrm{Na}]^{+}$: calculated for $\left[\mathrm{C}_{16} \mathrm{H}_{17} \mathrm{BrNaO}_{3} \mathrm{~S}\right]^{+}:$390.9979. Found: 390.9974. IR (KBr), $\nu, \mathrm{cm}^{-1}: 3489,1251,1158,1127,1081,771$, 639, 585, 540, 522, 486.

1-[(4-Methylphenyl)sulfonyl]-2-(4-nitrophenyl)propan-2-ol (3ia). ${ }^{16}$. White solid, $\mathrm{mp}=137.5-138.5{ }^{\circ} \mathrm{C}$ (lit. ${ }^{16} \mathrm{mp}=140.0$ $142.0{ }^{\circ} \mathrm{C}$ ). Yield 89\%. $R_{\mathrm{f}}=0.40$ (TLC, PE : EA, $2: 1$ ). ${ }^{1} \mathrm{H}$ NMR $\left(\right.$ DMSO $\left.\mathrm{d}_{6}\right), \delta: 1.57(\mathrm{~s}, 3 \mathrm{H}), 2.33(\mathrm{~s}, 3 \mathrm{H}), 3.84(\mathrm{~d}, J=14.8 \mathrm{~Hz}, 1 \mathrm{H})$, $4.01(\mathrm{~d}, J=14.8 \mathrm{~Hz}, 1 \mathrm{H}), 5.71(\mathrm{~s}, 1 \mathrm{H}), 7.25(\mathrm{~d}, J=8.0 \mathrm{~Hz}, 2 \mathrm{H})$, $7.51(\mathrm{~d}, J=8.0 \mathrm{~Hz}, 2 \mathrm{H}), 7.64(\mathrm{~d}, J=8.9 \mathrm{~Hz}, 2 \mathrm{H}), 8.02(\mathrm{~d}, J=8.8$ $\mathrm{Hz}, 2 \mathrm{H}$ ). ${ }^{13} \mathrm{C}$ NMR (DMSO-d 6 ), $\delta: 21.0,30.5,65.7,71.8,122.6$,
126.7, 127.7, 129.2, 138.1, 143.6, 146.1, 153.7. Calculated for $\mathrm{C}_{16} \mathrm{H}_{17} \mathrm{NO}_{5} \mathrm{~S} \mathrm{C:} 57.30 \%, \mathrm{H}: 5.11 \%, \mathrm{~N}: 4.18 \%$, S: 9.56\%. Found C: $57.28 \%, \mathrm{H}: 5.08 \%, \mathrm{~N}: 4.16 \%, \mathrm{~S}: 9.48 \%$. HRMS (ESI) $m / z[\mathrm{M}+$ $\mathrm{Na}]^{+}$: calculated for $\left[\mathrm{C}_{16} \mathrm{H}_{17} \mathrm{NNaO}_{5} \mathrm{~S}\right]^{+}:$358.0725. Found: 358.0713. IR (KBr), $\nu, \mathrm{cm}^{-1}$ : 3480, 1520, 1349, 1310, 1301, 1291, 1268, 1147, 1121, 1084, 855, 815, 757, 537, 518.

1-[(4-Methylphenyl)sulfonyl]-2-(4-methoxyphenyl)propan-2ol (3ja). ${ }^{16}$. White solid, $\mathrm{mp}=90-93{ }^{\circ} \mathrm{C}\left(\right.$ lit. $\left.^{16} \mathrm{mp}=94.5-95.5{ }^{\circ} \mathrm{C}\right)$. Yield 90\%. $R_{\mathrm{f}}=0.25$ (TLC, PE : EA, $\left.3: 1\right) .{ }^{1} \mathrm{H}$ NMR $\left(\mathrm{CDCl}_{3}\right), \delta$ : $1.66(\mathrm{~s}, 3 \mathrm{H}), 2.37$ (s, 3H), $3.54(\mathrm{~d}, J=14.5 \mathrm{~Hz}, 1 \mathrm{H}), 3.67$ (d, $J=$ $14.5 \mathrm{~Hz} \mathrm{1H}), 3.74$ (s, 3H), 6.68 (d, $J=8.8 \mathrm{~Hz}, 2 \mathrm{H}), 7.16$ (d, $J=8.3$ $\mathrm{Hz}, 2 \mathrm{H}$ ), 7.17 (d, $J=8.8 \mathrm{~Hz}, 2 \mathrm{H}), 7.47$ (d, $J=8.3 \mathrm{~Hz}, 2 \mathrm{H}) .{ }^{13} \mathrm{C}$ NMR $\left(\mathrm{CDCl}_{3}\right), \delta: 21.5,30.7,55.2,66.8,72.8,113.5,125.8,127.5$, 129.6, 136.6, 137.4, 144.3, 158.7. Calculated for $\mathrm{C}_{17} \mathrm{H}_{20} \mathrm{O}_{4} \mathrm{~S}$ C: 63.73\%, H: 6.29\%, S: 10.01\%. Found C: $63.88 \%$, H: $6.29 \%$, S: $10.01 \%$. HRMS (ESI) $\mathrm{m} / z \quad[\mathrm{M}+\mathrm{Na}]^{+}:$calculated for $\left[\mathrm{C}_{17} \mathrm{H}_{20} \mathrm{NaO}_{4} \mathrm{~S}\right]^{+}$: 343.0980. Found: 343.0975. IR (KBr), $\nu, \mathrm{cm}^{-1}$ : 3472, 1607, 1598, 1514, 1309, 1292, 1251, 1183, 1146, 1120, 1083, 1032, 832, 823, 810, 766, 676, 557, 536, 513.

1-[(4-Bromophenyl)sulfonyl]-2-phenylpropan-2-ol $\quad(3 \mathrm{fc}){ }^{\mathbf{1 6}}$ Yellow solid, $\mathrm{mp}=153-156{ }^{\circ} \mathrm{C}$ (lit. ${ }^{16} \mathrm{mp}=153.0-153.5{ }^{\circ} \mathrm{C}$ ). Yield $52 \% . R_{\mathrm{f}}=0.40$ (TLC, PE : EA, $\left.3: 1\right) .{ }^{1} \mathrm{H}$ NMR $\left(\mathrm{DMSO}_{6}\right)$, $\delta: 1.60(\mathrm{~s}, 3 \mathrm{H}), 3.86(\mathrm{~s}, 2 \mathrm{H}), 4.75(\mathrm{br} \mathrm{s}, 1 \mathrm{H}), 7.11-7.23(\mathrm{~m}, 3 \mathrm{H})$, $7.33-7.39(\mathrm{~m}, 2 \mathrm{H}), 7.62(\mathrm{~d}, J=8.6 \mathrm{~Hz}, 2 \mathrm{H}), 7.70(\mathrm{~d}, J=8.6 \mathrm{~Hz}$, $2 \mathrm{H}) .{ }^{13} \mathrm{C}$ NMR (DMSO-d 6 ), $\delta: 29.9,66.1,71.7,125.0,126.4$, 127.1, 127.6, 129.8, 131.7, 140.6, 146.5. Calculated for $\mathrm{C}_{15} \mathrm{H}_{15} \mathrm{BrO}_{3} \mathrm{~S}$ C: $50.71 \%, \mathrm{H}: 4.26 \%, \mathrm{Br}: 22.49 \%$, S: $9.03 \%$. Found C: $50.78 \%$, H: $4.31 \%$, Br: $22.48 \%$, S: $9.02 \%$. HRMS (ESI) $\mathrm{m} / \mathrm{z}$ $[\mathrm{M}+\mathrm{Na}]^{+}$: calculated for $\left[\mathrm{C}_{15} \mathrm{H}_{15} \mathrm{BrNaO}_{3} \mathrm{~S}\right]^{+}:$376.9823. Found: 376.9821. IR (KBr), $\nu, \mathrm{cm}^{-1}: 3507,1576,1392,1312$, 1295, 1270, 1149, 1122, 1084, 1067, 1010, 942, 821, 775, 765, 714, 701, 579, $545,528,411$.

1-[(4-Methoxyphenyl)sulfonyl]-2-phenylpropan-2-ol $\quad(3 \mathrm{fd}){ }^{16}$ White solid, $\mathrm{mp}=87.5-89{ }^{\circ} \mathrm{C}$ (lit. ${ }^{16} \mathrm{mp}=90.5-92.5{ }^{\circ} \mathrm{C}$ ). Yield $85 \% . R_{\mathrm{f}}=0.45$ (TLC, PE : EA, $\left.2: 1\right) .{ }^{1} \mathrm{H} \mathrm{NMR}\left(\mathrm{CDCl}_{3}\right), \delta: 1.68(\mathrm{~s}$, $3 \mathrm{H}), 3.58(\mathrm{~d}, J=14.7 \mathrm{~Hz}, 1 \mathrm{H}), 3.70(\mathrm{~d}, J=14.7 \mathrm{~Hz}, 1 \mathrm{H}), 3.82(\mathrm{~s}$, $3 \mathrm{H}), 6.81(\mathrm{~d}, J=8.9 \mathrm{~Hz}, 2 \mathrm{H}), 7.11-7.24(\mathrm{~m}, 3 \mathrm{H}), 7.25-7.31(\mathrm{~m}$, $2 \mathrm{H}), 7.50(\mathrm{~d}, J=8.9 \mathrm{~Hz}, 2 \mathrm{H}) .{ }^{13} \mathrm{C} \mathrm{NMR}\left(\mathrm{CDCl}_{3}\right), \delta: 30.8,55.6$, 66.7, 73.0, 114.2, 124.6, 127.1, 128.2, 129.7, 131.8, 144.5, 163.5. Calculated for $\mathrm{C}_{16} \mathrm{H}_{18} \mathrm{O}_{4} \mathrm{~S}$ C: $62.72 \%, \mathrm{H}: 5.92 \%$, S: $10.47 \%$. Found C: $62.81 \%$, H: 5.95\%, S: 10.46\%. HRMS (ESI) $m / z[\mathrm{M}+$ $\mathrm{Na}]^{+}$: calculated for $\left[\mathrm{C}_{16} \mathrm{H}_{18} \mathrm{NaO}_{4} \mathrm{~S}\right]^{+}$: 329.0824. Found: 329.0813 . IR $(\mathrm{KBr}), \nu, \mathrm{cm}^{-1}: 3501,1594,1497,1307,1295,1261,1249$, 1151, 1117, 1079, 1026, 830, 758, 697, 570, 529, 480, 468.

1-[(4-Nitrophenyl)sulfonyl]-2-phenylpropan-2-ol $\quad$ (3fe). ${ }^{\mathbf{1 6}}$ White solid, $\mathrm{mp}=177.5-179.5^{\circ} \mathrm{C}$ (lit. ${ }^{16} \mathrm{mp}=187-190{ }^{\circ} \mathrm{C}$ ). Yield $36 \% . R_{\mathrm{f}}=0.25$ (TLC, PE : EA, $\left.3: 1\right) .{ }^{1} \mathrm{H}$ NMR $\left(\right.$ DMSO-d $\left._{6}\right), \delta: 1.61$ (s, 3H), 3.93-4.05 (m, 2H), $5.44(\mathrm{~s}, 1 \mathrm{H}), 7.08-7.23(\mathrm{~m}, 3 \mathrm{H}), 7.31-$ $7.39(\mathrm{~m}, 2 \mathrm{H}), 7.96(\mathrm{~d}, J=8.7 \mathrm{~Hz}, 2 \mathrm{H}), 8.29(\mathrm{~d}, J=8.7 \mathrm{~Hz}, 2 \mathrm{H}) .{ }^{13} \mathrm{C}$ NMR (DMSO-d d ) $\delta:$ 29.9, 65.8, 71.6, 123.7, 124.9, 126.4, 127.5, 129.4, 146.3, 146.6, 149.7. Calculated for $\mathrm{C}_{15} \mathrm{H}_{15} \mathrm{NO}_{5} \mathrm{~S} \mathrm{C}$ : $56.06 \%, \mathrm{H}: 4.70 \%, \mathrm{~N}: 4.36 \%$, S: $9.98 \%$. Found C: $56.04 \%, \mathrm{H}$ : 4.85\%, N: 4.21\%, S: 9.96\%. HRMS (ESI) $m / z[\mathrm{M}+\mathrm{Na}]^{+}$: calculated for $\left[\mathrm{C}_{15} \mathrm{H}_{15} \mathrm{NNaO}_{5} \mathrm{~S}\right]^{+}:$344.0569. Found: 344.0563. IR (KBr), $\nu$, $\mathrm{cm}^{-1}$ : 3492, 1525, 1350, 1305, 1148, 1121, 1083, 849, 771, 742, 579,525 . 


\section{Acknowledgements}

This work was supported by the Russian Science Foundation (Grant 14-23-00150).

\section{References}

1 H. Eto, Y. Kaneko, S. Takeda, M. Tokizawa, S. Sato, K. Yoshida, S. Namiki, M. Ogawa, K. Maebashi, K. Ishida, M. Matsumoto and T. Asaoka, Chem. Pharm. Bull., 2001, 49, 173.

2 B. J. A. Furr, Horm. Res., 1989, 32, 69.

3 T. Sato, Y. Okumura, J. Itai and T. Fujisawa, Chem. Lett., 1988, 17, 1537.

4 M. Julia and J.-M. Paris, Tetrahedron Lett., 1973, 14, 4833.

5 N. Suryakiran, T. Srikanth Reddy and Y. Venkateswarlu, J. Sulfur Chem., 2007, 28, 513.

6 A. K. Maiti and P. Bhattacharyya, Tetrahedron, 1994, 50, 10483.

7 D. J. Berrisford, P. A. Lovell, N. R. Suliman and A. Whiting, Chem. Commun., 2005, 5904.

8 S. Narayana Murthy, B. Madhav, V. Prakash Reddy, K. Rama Rao and Y. V. D. Nageswar, Tetrahedron Lett., 2009, 50, 5009.

9 M. C. Bernabeu, P. Bonete, F. Caturla, R. Chinchilla and C. Nájera, Tetrahedron: Asymmetry, 1996, 7, 2475.

10 P. Bertus, P. Phansavath, V. Ratovelomanana-Vidal, J. P. Genêt, A. R. Touati, T. Homri and B. B. Hassine, Tetrahedron Lett., 1999, 40, 3175.

11 A. L. Moure, R. G. Arrayas and J. C. Carretero, Chem. Commun., 2011, 47, 6701.

12 W. Autenrieth, Liebigs Ann. Chem., 1890, 259, 362.

13 W. E. Truce and A. M. Murphy, Chem. Rev., 1951, 48, 69.

14 W. Wei, J. Wen, D. Yang, H. Jing, J. You and H. Wang, RSC Adv., 2015, 5, 4416.

15 Q. Lu, J. Zhang, F. Wei, Y. Qi, H. Wang, Z. Liu and A. Lei, Angew. Chem., Int. Ed., 2013, 52, 7156.

16 T. Taniguchi, A. Idota and H. Ishibashi, Org. Biomol. Chem., 2011, 9, 3151.

17 X. Tang, L. Huang, Y. Xu, J. Yang, W. Wu and H. Jiang, Angew. Chem., Int. Ed., 2014, 53, 4205.

18 W. Wei, J. Li, D. Yang, J. Wen, Y. Jiao, J. You and H. Wang, Org. Biomol. Chem., 2014, 12, 1861.

19 V. Nair, A. Augustine, T. G. George and L. G. Nair, Tetrahedron Lett., 2001, 42, 6763.

20 Y. Gao, W. Wu, Y. Huang, K. Huang and H. Jiang, Org. Chem. Front., 2014, 1, 361.

21 W. Wei, J. Wen, D. Yang, J. Du, J. You and H. Wang, Green Chem., 2014, 16, 2988.

22 L. Zhang, S. Chen, Y. Gao, P. Zhang, Y. Wu, G. Tang and Y. Zhao, Org. Lett., 2016, 18, 1286.

23 F. Xiao, H. Chen, H. Xie, S. Chen, L. Yang and G. J. Deng, Org. Lett., 2014, 16, 50.

24 J. K. Qiu, W. J. Hao, D. C. Wang, P. Wei, J. Sun, B. Jiang and S. J. Tu, Chem. Commun., 2014, 50, 14782.

25 W. Wei, J. Wen, D. Yang, M. Guo, Y. Wang, J. You and H. Wang, Chem. Commun., 2015, 51, 768.

26 K. M. Gligorich and M. S. Sigman, Chem. Commun., 2009, 3854 .
27 Z. Shi, C. Zhang, C. Tang and N. Jiao, Chem. Soc. Rev., 2012, 41, 3381.

28 A. N. Campbell and S. S. Stahl, Acc. Chem. Res., 2012, 45, 851. 29 W. Wei, J. Wen, D. Yang, M. Wu, J. You and H. Wang, Org. Biomol. Chem., 2014, 12, 7678.

30 L. C. Anderson and N. W. MacNaughton, J. Am. Chem. Soc., 1942, 64, 1456.

31 R. Barnes, J. Graham and M. Taylor, J. Org. Chem., 1958, 23, 1561.

32 S. Chakraborty, P. Bhattacharya, H. Dai and H. Guan, Acc. Chem. Res., 2015, 48, 1995.

33 X. Li, X. Xu and C. Zhou, Chem. Commun., 2012, 48, 12240.

34 W. Wei, C. Liu, D. Yang, J. Wen, J. You, Y. Suo and H. Wang, Chem. Commun., 2013, 49, 10239.

35 J. Wen, W. Wei, S. Xue, D. Yang, Y. Lou, C. Gao and H. Wang, J. Org. Chem., 2015, 80, 4966.

36 V. K. Sharma and F. J. Millero, Environ. Sci. Technol., 1988, 22, 768.

37 B. M. Voelker, D. L. Sedlak and O. C. Zafiriou, Environ. Sci. Technol., 2000, 34, 1036.

38 M. González-Dávila, J. M. Santana-Casiano, A. G. González, N. Pérez and F. J. Millero, Mar. Chem., 2009, 115, 118.

39 X. Yuan, A. N. Pham, G. Xing, A. L. Rose and T. D. Waite, Environ. Sci. Technol., 2012, 46, 1527.

40 P. Zhou, J. Zhang, Y. Zhang, Y. Liu, J. Liang, B. Liu and W. Zhang, RSC Adv., 2016, 6, 38541.

41 G. W. Filson and J. H. Walton, J. Phys. Chem., 1931, 36, 740. 42 P. M. Henry, Inorg. Chem., 1966, 5, 688.

43 A. S. Jhaveri and M. M. Sharma, Chem. Eng. Sci., 1967, 22, 1. 44 R. D. Gray, J. Am. Chem. Soc., 1969, 91, 56.

45 T. Taniguchi, H. Zaimoku and H. Ishibashi, Chem.-Eur. J., 2011, 17, 4307.

46 M. Kharasch and A. Fono, J. Org. Chem., 1958, 23, 324.

47 M. S. Kharasch and A. Fono, J. Org. Chem., 1959, 24, 606.

48 M. S. Kharasch, G. Sosnovsky and N. C. Yang, J. Am. Chem.

Soc., 1959, 81, 5819.

49 G. Sosnovsky and N. C. Yang, J. Org. Chem., 1960, 25, 899.

50 J. K. Kochi, J. Am. Chem. Soc., 1961, 83, 3162.

51 J. K. Kochi, J. Am. Chem. Soc., 1963, 85, 1958.

52 S. H. Oh, Y. R. Malpani, N. Ha, Y. S. Jung and S. B. Han, Org. Lett., 2014, 16, 1310.

53 K. Sun, Y. Lv, Z. Zhu, Y. Jiang, J. Qi, H. Wu, Z. Zhang, G. Zhang and X. Wang, RSC Adv., 2015, 5, 50701.

54 S. F. Zhou, D. P. Li, K. Liu, J. P. Zou and O. T. Asekun, J. Org. Chem., 2015, 80, 1214.

55 H. R. Lucas, L. Li, A. A. Sarjeant, M. A. Vance, E. I. Solomon and K. D. Karlin, J. Am. Chem. Soc., 2009, 131, 3230-3245.

56 S. Lim, M. Ji, X. Wang, C. Lee and H.-Y. Jang, Eur. J. Org. Chem., 2015, 591.

57 M. Catir, H. Kilic, V. Nardello-Rataj, J. M. Aubry and C. Kazaz, J. Org. Chem., 2009, 74, 4560.

58 M. Nakano, K. Takayama, Y. Shimizu, Y. Tsuji, H. Inaba and T. Migita, J. Am. Chem. Soc., 1976, 98, 1974.

59 A. M. Tsedilin, A. N. Fakhrutdinov, D. B. Eremin, S. S. Zalesskiy, A. O. Chizhov, N. G. Kolotyrkina and V. P. Ananikov, Mendeleev Commun., 2015, 25, 454-456. 
60 A. J. Perkowski, W. You and D. A. Nicewicz, J. Am. Chem. Soc., 2015, 137, 7580.

61 G. L. Backes, B. S. Jursic and D. M. Neumann, Bioorg. Med. Chem., 2015, 23, 3397.

62 G. Zhang, X. Xie, Y. Wang, X. Wen, Y. Zhao and C. Ding, Org. Biomol. Chem., 2013, 11, 2947.

63 C. B. Tripathi and S. Mukherjee, Angew. Chem., Int. Ed., 2013, 52, 8450.

64 T. N. Gieshoff, M. Villa, A. Welther, M. Plois, U. Chakraborty, R. Wolf and A. Jacobi von Wangelin, Green Chem., 2015, 17, 1408.

65 H. Lebel, M. Davi, S. Diez-Gonzalez and S. P. Nolan, J. Org. Chem., 2007, 72, 144.
66 N. C. Deno, F. A. Kish and H. J. Peterson, J. Am. Chem. Soc., 1965, 87, 2157.

67 H. Zinner, H. Brenken, W. Braun, I. Falk, E. Fechtner and E. Hähner, Liebigs Ann. Chem., 1959, 622, 133.

68 C. B. Tripathi and S. Mukherjee, Org. Lett., 2014, 16, 3368.

69 K. M. Khan, U. Salar, M. I. Fakhri, M. Taha, A. Hameed, S. Perveen and W. Voelter, Lett. Org. Chem., 2015, $12,637$.

70 N. Taniguchi, J. Org. Chem., 2015, 80, 7797.

71 Y. Tang, Y. Zhang, K. Wang, X. Li, X. Xu and X. Du, Org. Biomol. Chem., 2015, 13, 7084.

72 S. Handa, J. C. Fennewald and B. H. Lipshutz, Angew. Chem., Int. Ed., 2014, 53, 3432.

73 D. F. Tavares and P. F. Vogt, Can. J. Chem., 1967, 45, 1519. 